\title{
Identification of LRP-1 as an endocytosis and recycling receptor for $\beta 1$-integrin in thyroid cancer cells
}

\author{
Louis Theret ${ }^{1,2}$, Albin Jeanne ${ }^{1,2,3}$, Benoit Langlois ${ }^{1,2}$, Cathy Hachet ${ }^{1,2}$, Marion David ${ }^{4}$, \\ Michel Khrestchatisky ${ }^{5}$, Jérôme Devy ${ }^{1,2}$, Emonard Hervé ${ }^{1,2}$, Sébastien Almagro ${ }^{1,2}$ \\ and Stéphane Dedieu ${ }^{1,2}$ \\ ${ }^{1}$ Université de Reims Champagne-Ardenne, UFR Sciences Exactes et Naturelles, Reims, France \\ ${ }^{2}$ CNRS UMR 7369, Matrice Extracellulaire et Dynamique Cellulaire, MEDyC, Reims, France \\ ${ }^{3}$ SATT Nord, Lille, France \\ ${ }^{4}$ VECT-HORUS SAS, Faculté de Médecine Secteur Nord, Marseille, France \\ ${ }^{5}$ Aix Marseille Université, CNRS, NICN, Marseille, France \\ Correspondence to: Stéphane Dedieu, email: stephane.dedieu@univ-reims.fr \\ Keywords: LRP-1, $\beta 1$-integrin, cancer, endocytosis, recycling
}

Received: March 31, $2017 \quad$ Accepted: July 25, $2017 \quad$ Published: August 10, 2017

Copyright: Theret et al. This is an open-access article distributed under the terms of the Creative Commons Attribution License 3.0 (CC BY 3.0), which permits unrestricted use, distribution, and reproduction in any medium, provided the original author and source are credited.

\section{ABSTRACT}

LRP-1 is a large endocytic receptor mediating the clearance of various molecules from the extracellular matrix. LRP-1 was reported to control focal adhesion turnover to optimize the adhesion-deadhesion balance to support invasion. To better understand how LRP-1 coordinates cell-extracellular matrix interface, we explored its ability to regulate cell surface integrins in thyroid carcinomas. Using an antibody approach, we demonstrated that $\beta 1$-integrin levels were increased at the plasma membrane under LRP1 silencing or upon RAP treatment, used as LRP-1 antagonist. Our data revealed that LRP-1 binds with both inactive and active $\beta 1$-integrin conformations and identified the extracellular ligand-binding domains II or IV of LRP-1 as sufficient to bind $\beta 1$-integrin. Using a recombinant $\beta 1$-integrin, we demonstrated that LRP-1 acts as a regulator of $\beta 1$-integrin intracellular traffic. Moreover, RAP or LRP-1 blocking antibodies decreased up to $36 \%$ the number of $\beta 1$-integrin-containing endosomes. LRP-1 blockade did not significantly affect the levels of $\beta 1$-integrin-containing lysosomes while decreasing localization of $\beta 1$-integrin within Rab-11 positive vesicles. Overall, we identified an original molecular process in which LRP-1 acts as a main regulator of $\beta 1$-integrin internalization and recycling in thyroid cancer cells.

\section{INTRODUCTION}

The low-density lipoprotein receptor-related protein-1 (LRP-1) is a large multifunctional endocytic receptor belonging to the low-density lipoprotein receptor family. First described for its role in lipoprotein metabolism [1], LRP-1 has since been shown to be involved in many physiological and pathological processes including control of the hepatic function and cholesterol homeostasis [2], vascular integrity [3] and blood-brain barrier permeability [4] as well as Alzheimer disease [5] and cancer development [6]. While initially synthesized as a $600 \mathrm{kDa}$ precursor, LRP-1 is rapidly cleaved by a furine convertase into two non-covalently linked chains, i.e. a $515 \mathrm{kDa} \alpha$-chain and an $85 \mathrm{kDa}$ transmembrane $\beta$-chain comprising the intra-cytoplasmic domain. The $\alpha$-chain is exclusively extracellular and holds four cysteinrich domains allowing LRP-1 to interact with more than thirty soluble or membrane-anchored ligands. The intracytoplasmic domain of the $\beta$-chain consists of a short 100 amino-acid cytoplasmic tail containing two NPXY motifs with the distal one overlapping an YXXL sequence, 
which are crucial for recruiting molecular adaptors as well as signaling proteins and to trigger endocytosis, respectively [7].

Through its endocytic activity, LRP-1 mediates internalization and catabolism of various extracellular proteinases, therefore limiting extracellular matrix (ECM) remodeling [8, 9]. Clearance of the uPA (urokinase plaminogen activator receptor)/PAI-1 (plasminogen activator inhibitor-1) complex can be achieved through uPAR binding to LRP-1, thus leading to uPA:PAI-1 lysosomal degradation, uPAR recycling and subsequent regulation of the plasmin activation cascade [10]. In addition, LRP-1 has been shown to be a key player in the clearance of matrix metalloproteinases (MMPs) i.e. MMP2 [11], -9 [12], -13 [13] but also ADAMTS (a disintegrin and metalloproteinase with thrombospondin motifs)-4 [14] and ADAMTS-5 [15]. The aspartic protease cathepsin-D, whose overexpression is correlated with poor prognosis in breast cancer, is also endocytosed by LRP-1 [16]. As a consequence of its well-identified function in controlling extracellular proteolysis, LRP-1 was initially considered as preventing tumor aggressiveness [8]. This was reinforced by studies conducted in rodents or considering human samples that both further confirmed the existing correlation between low LRP-1 expression levels and poor survival [17-19]. Despite these experimental and clinical data, the overall contribution of LRP-1 to tumor progression appears actually much more complex, remaining mostly misunderstood and somehow controversial. Previous work has reported LRP-1 as supporting invasion, survival or metastatic dissemination of thyroid carcinoma [20,21] and breast cancer cells [22-24]. Consistently, C766T LRP1 gene polymorphism, which has been previously associated with neurodegenerative disease [25], also correlates with increased breast cancer occurrence [26]. More recently, an elegant network-based exploratory study found LRP-1 as being highly connected to a multi-cancer gene expression biomarker, which appears to be strongly predictive of clinical outcome in 12 types of cancers [27]. In order to comprehensively clarify the function of this endocytic receptor in tumor cells, others have sought to decipher LRP-1-related molecular mechanisms and signaling pathways. Since then, it has been demonstrated that the cell surface expression of LRP-1 is frequently increased at the invasive front, especially within adhesion and actinrich structures [22, 28]. In addition, LRP-1 interaction with membrane-bound calreticulin was shown to stimulate focal adhesion reorganization in non-cancer cells [29]. In a tumor context, we previously demonstrated that LRP1 controls actin cytoskeleton organization and focal adhesion complex turnover [20,30]. LRP-1 is required to ensure the appropriate distribution of paxillin and FAK (focal adhesion kinase) within focal adhesions and contributes to optimize thyroid carcinoma cell adhesion and invasion by supporting ERK (extracellular signalregulated kinases) and concomitantly inhibiting JNK (c-jun N-terminal kinase) pathways [21]. Furthermore, we recently identified LRP-1 as a main endocytic receptor for the hyaluronan receptor CD44, hence fundamentally regulating tumor cell morphology and ECM attachment [28].

In view of the above, one should consider LRP-1 as a main regulator of cell-matrix interaction dynamics acting via coordination of the adhesion-deadhesion balance, especially within a tumor microenvironment. Nevertheless, the relatively poor knowledge of LRP-1 transmembrane interactome impedes our thorough understanding of the way it controls cell-matrix interaction dynamics and contributes to malignant disease progression. Among the range of possibilities, both integrins and LRP-1 appear to be engaged in similar molecular pathways regulating cell adhesion, spreading and motility [31, 32]. With the purpose of establishing an integrated functional relationship between LRP-1-mediated endocytosis and cell-ECM interface, we here explored the ability of LRP1 to bind cell surface integrins to regulate their uptake and recycling in tumor cells.

\section{RESULTS}

\section{Cell surface $\beta 1$-integrin accumulates under LRP-1 inhibition}

To assess whether LRP-1 may regulate cell surface integrins, we used both LRPI silencing strategy and treatment with the LRP-1 antagonist RAP (receptorassociated protein) in order to inhibit LRP-1-mediated endocytosis. Assays were carried out in FTC-133 cells that remain a favored cellular model of LRP-1 study in the tumor context [20, 28, 33, 34]. Selective $L R P 1$ silencing was conducted using previously validated short interfering sequences [20] and reached about $70 \%$ downregulation of endogenous LRP-1 expression at both mRNA and protein levels (Figure 1A and 1B). LRP-1 ability to mediate endocytosis was then analyzed under these experimental conditions using FITC-labelled $\alpha 2$-macroglobulin as a control ligand [28]. The results confirm that both RAP treatment and LRP-1 silencing inhibit the internalization of labeled substrate by approximately 2- and 3-fold, respectively (Figure 1C). To investigate whether LRP-1 may regulate the level of integrin at the plasma membrane, we then used an antibody array approach to quantify cell surface $\alpha$ - and $\beta$-integrin subunits (Figure $1 \mathrm{D}$ to $1 \mathrm{G}$ ). Under control conditions, a wide range of integrins was expressed at the cell surface of FTC-133 thyroid carcinomas, particularly integrin subunits $\alpha 2, \alpha 3, \alpha 5, \alpha \mathrm{v}$, $\beta 1$ and $\beta 2$ (Figure $1 \mathrm{E}$ and $1 \mathrm{G}$ ). Neither LRP1 silencing (Figure 1D) nor its functional inhibition using RAP treatment (Figure 1E) affected the $\alpha$-integrin subunits expression at the cell surface. Interestingly, both $\beta 1$ and $\beta 2$ integrins were found to significantly accumulate at the plasma membrane of FTC-133 cells under LRP1 silencing, 
A

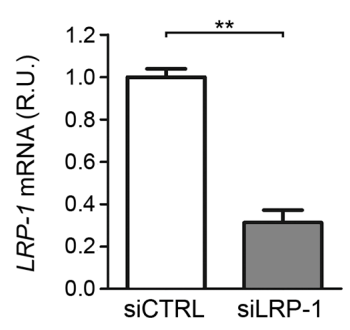

C

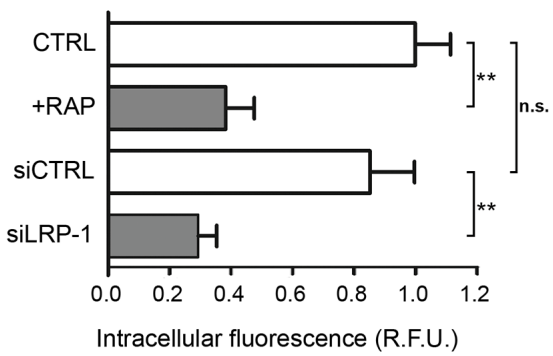

B

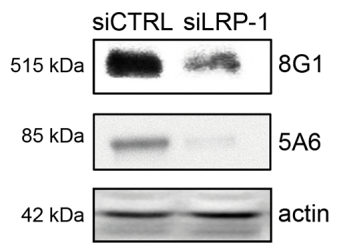

D

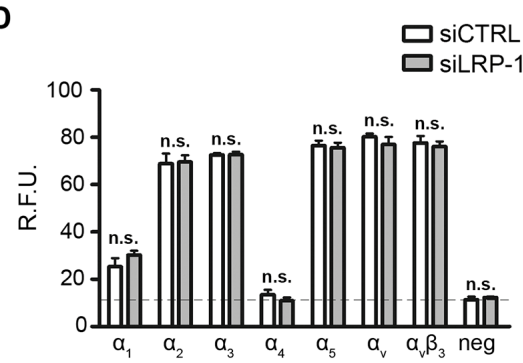

$\mathbf{F}$

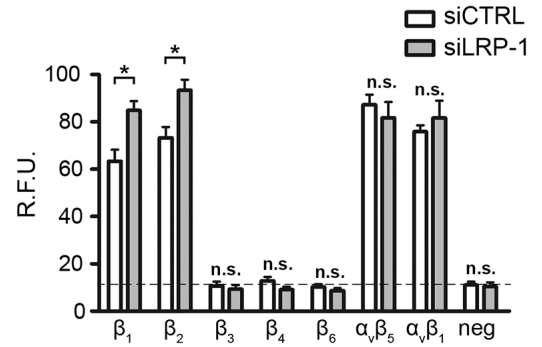

E

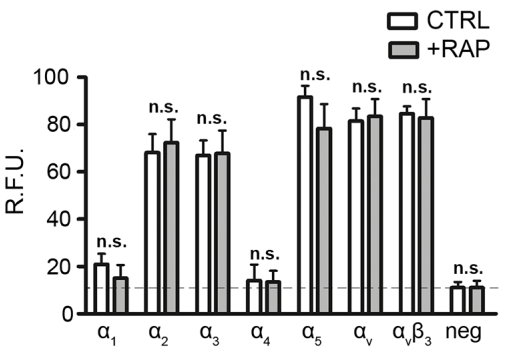

G

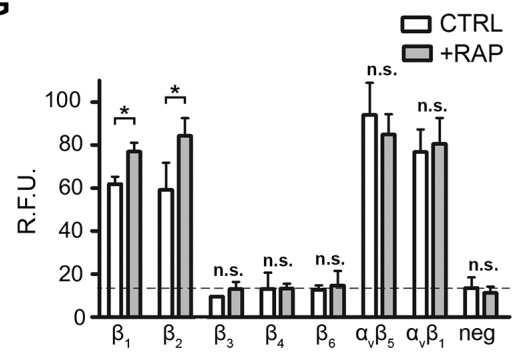

Figure 1: Cell surface $\beta 1$-integrin accumulates under LRP-1 inhibition or silencing. (A) Total RNAs were purified from FTC133 cells transfected with non-silencing siRNA (siCTRL) or siRNA targeting LRP1 (siLRP-1). LRP1 mRNA expression was quantified using real-time RT-PCR and expressed as relative units (R.U.). RPL32 and RS18 were used for normalization. siCTRL cells served as a reference set to 1. (B) LRP-1 protein expression from FTC-133 cells transfected with non-silencing siRNA (siCTRL) or siRNA targeting LRP1 (siLRP-1) was assessed by SDS-PAGE immunoblotting of LRP-1 $\alpha$ chain (8G1) and LRP-1 $\beta$ chain (5A6). (C) Wild-type FTC-133 cells (WT) were treated in presence or absence of $500 \mathrm{nM}$ RAP or transfected with siRNA sequences (siCTRL and siLRP-1), and then incubated for $30 \mathrm{~min}$ in serum-free medium containing FITC-labeled human $\alpha 2$-macroglobulin. The intracellular fluorescence reflecting endocytosis activity was determined as described elsewhere [20] and is expressed as relative fluorescence units (R.F.U.), by comparison with signal from untreated WT cells (CTRL). (D-G) $\alpha$ - and $\beta$-integrin subunits were quantified at FTC-133 cell surface using an antibody array under LRP1 silencing (siLRP-1) (D and F) or $500 \mathrm{nM}$ RAP treatment (E and G). The specific signal threshold was established using negative controls (neg) and is represented by dotted lines. Each value is the mean \pm SD for at least three independent experiments, each performed in triplicate. n.s., not significant; ${ }^{*}, \mathrm{P}<0.05$; ${ }^{*}, \mathrm{P}<0.01$; as compared to the corresponding CTRL or siCTRL condition (white bars). 
with about $25 \%$ increase in measured signals (Figure $1 \mathrm{~F}$ ). None of the other $\beta$-integrin subunits appeared affected by $L R P 1$ downregulation. Consistently, similar results were obtained under RAP treatments (Figure 1G).

\section{LRP-1 and $\beta 1$-integrin coexist within the same molecular complexes}

Considering the results displayed in Figure $1 \mathrm{~F}$ and $1 \mathrm{G}$ and that $\beta 2$-integrin is especially relevant as a leukocyte receptor [35], we investigated whether LRP-1 may interface with $\beta 1$-integrin. First, co- immunoprecipitation assays were carried out from whole cell extracts (Figure 2A and 2B) and plasma membrane extracts (Figure 2C). The 8G1 antibody, which is directed against the extracellular LRP-1 $\alpha$-chain, allowed immunoprecipitation of both LRP-1 $\alpha$ - and $\beta$-chains (Figure $2 \mathrm{~A}$ and $2 \mathrm{C}$ ). Total $\beta 1$-integrin (M-106) was found co-immunoprecipitated with LRP-1 from whole cell extracts (Figure 2A). Reverse immunoprecipitation experiments with anti- $\beta 1$-integrin were also performed with the same cell lysates. The data presented in Figure 2B confirmed that LRP-1 and $\beta 1$-integrin were detected in the same molecular complex. Immunoprecipitations were
A

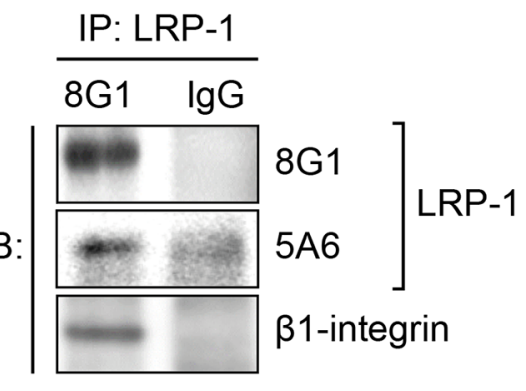

C

\section{Cell surface proteins}

IP: $8 \mathrm{G} 1 \mathrm{lgG}$

IB:

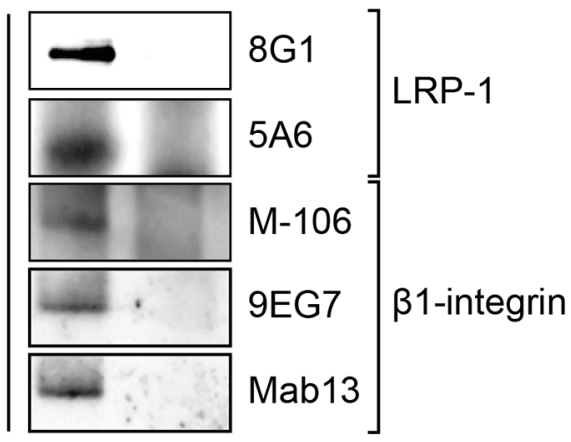

B

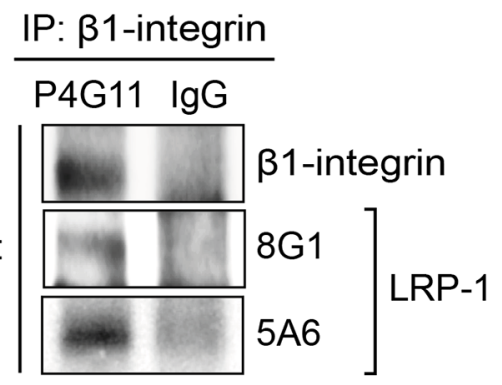

Figure 2: LRP-1 and $\beta 1$-integrin are found in the same molecular complexes in thyroid cancer cells. (A) Whole-cell extracts were isolated from FTC-133 cells. Immunoprecipitations of LRP-1 $\alpha$-chain-containing complexes were carried out using antiLRP-1 $\alpha$-chain (8G1), and then isolated immunocomplexes were immunoblotted using anti-LRP-1 $\alpha$-chain (8G1), anti-LRP-1 $\beta$-chain (5A6) and anti- $\beta 1$-integrin (M-106) antibodies. (B) A reverse immunoprecipitation assay was conducted from FTC-133 whole-cell extracts using anti- $\beta 1$-integrin antibody (P4G11) under experimental conditions described above. (C) Biotinylation of FTC-133 cell surface proteins was conducted at $4^{\circ} \mathrm{C}$, and biotinylated proteins were isolated using avidin-agarose beads. Cell surface LRP-1-containing complexes were immunoprecipitated using anti-LRP-1 $\alpha$-chain (8G1) and immunoblotted using 8G1, anti-LRP-1 $\beta$-chain (5A6), anti- $\beta 1$-integrin (M-106), anti-active $\beta 1$-integrin (9EG7) and anti-inactive $\beta 1$-integrin (Mab13) antibodies. (D) FTC-133 cells were transfected with HAtagged LRP-1 mini-receptors (SPCT, DIV and DII) or an empty plasmid (CTRL). Immunoprecipitations of HA-tagged LRP-1 minireceptors were performed using anti-HA antibody (HA-tag) and immunocomplexes were immunoblotted using anti- $\beta 1$-integrin antibody (M-106). All experiments were repeated three times with different sets of samples and nonspecific IgGs were used as a negative control for immunoprecipitation. 
also conducted using biotinylated proteins to examine cell surface LRP-1-containing complexes. Results displayed on Figure $2 \mathrm{C}$ revealed that $\beta 1$-integrin (M-106) was indeed co-immunoprecipitated with cell surface LRP-1. Using monoclonal antibodies designed to discriminate between active (9EG7) and inactive (Mab13) $\beta 1$-integrin conformation [36], we further observed that both $\beta 1$ integrin conformations may bind with cell surface LRP1 (Figure 2C). Next, in order to determine which part of LRP-1 is involved in $\beta 1$-integrin binding at the cell surface we overexpressed functional HA-tagged mini-receptors derived from full-length LRP-1 [28]. Immunoprecipitation was conducted from biotinylated cell surface proteins using anti-HA tag (Figure 2D). In this assay, endogenous $\beta 1$-integrin did not co-immunoprecipitate with the recombinant variant of LRP-1 exhibiting only the LRP-1 $\beta$-chain (SPCT). Conversely, LRP-1 constructs harboring the extracellular ligand-binding domains II or IV from the $\alpha$-chain were sufficient to bind $\beta 1$-integrin. Of note, larger amounts of endogenous $\beta 1$-integrin were immunoprecipitated when using LRP-1 ligand-binding domain II-harboring constructs.

Interestingly, results from immunoprecipitation assays carried out in various tumor (Figure 3A) and nontumor cells (Figure 3B) indicated that the LRP-1/ $\beta 1$ - integrin complex is not specific of thyroid carcinoma and likewise exists in many cellular environments.

\section{Endogenous LRP-1 and $\beta 1$-integrin are colocalized in thyroid carcinoma cells}

Having established that a LRP-1/ $\beta 1$-integrin complex occurs markedly at the plasma membrane of thyroid carcinoma cells (Figure 2C), we analyzed the cellular distribution of these proteins using confocal immunofluorescence microscopy (Figure 4). Superposition of LRP-1 (Figure 4A) and $\beta 1$-integrin (Figure 4B) images revealed that both endogenous proteins partially colocalized in tumor cells (Figure 4C). One could notice that the LRP-1/ $\beta 1$-integrin complexes were remarkably localized at the plasma membrane area, especially at the leading edge and along the lateral sides of the migrating cell (Figure 4C, insets). Regarding the cell shape, control carcinoma cells exhibited a polarized morphology with membrane protrusions typical of migrating cells (Figure 4D and 4E), in contrast with RAP-treated cells which exhibited an expected overspread and highly adherent phenotype (Figure 4F and 4G) [34]. Interestingly, distribution of LRP-1/ $\beta 1$-integrin complexes at the cell membrane was significantly decreased when RAP was

\section{A}
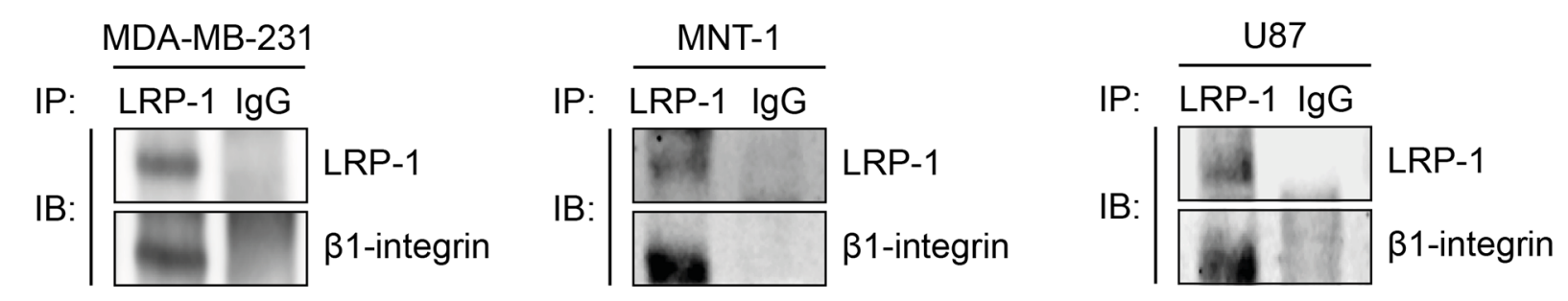

B
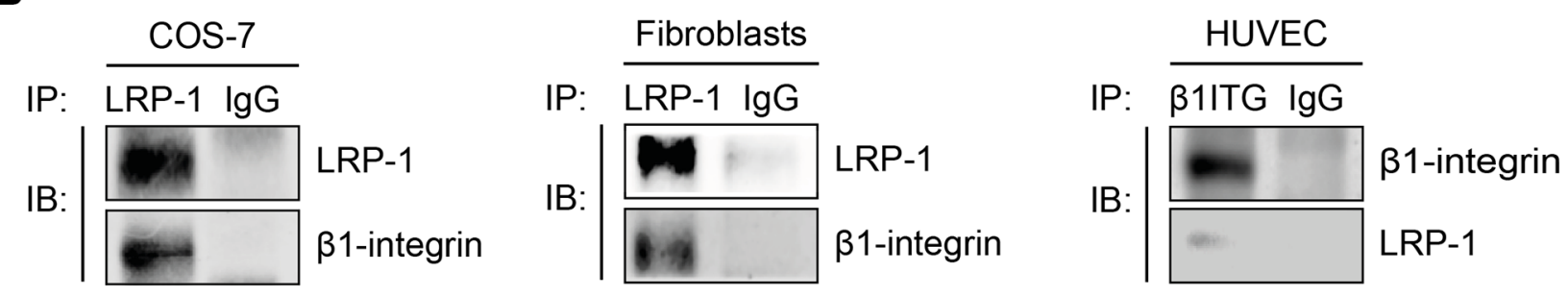

Figure 3: The LRP-1/ק1-integrin complex is not only established in thyroid carcinoma. Whole-cell extracts were isolated from breast tumor cells (A, left panel), melanoma cells (A, middle panel), glioblastoma cells (A, right panel), COS-7 cells (B, left panel), primary dermal fibroblast (B, middle panel) or endothelial cells (B, right panel). Immunoprecipitation of LRP-1 was conducted and immunocomplexes were immunoblotted using anti-LRP-1 and anti- $\beta 1$-integrin antibodies as described above. Considering the low level of LRP-1 expression in HUVECs, immunoprecipitations of $\beta 1$-integrin was favored. Nonspecific IgGs were used as a negative control for each assay. 
used to antagonize LRP-1-mediated endocytosis (Figure $4 \mathrm{D}$ to $4 \mathrm{G}$, insets).

\section{B1-integrin dynamics appears LRP-1 dependent}

We demonstrated that LRP-1 and $\beta 1$-integrin closely colocalized in thyroid carcinomas, and we thus investigated whether LRP-1 may contribute to $\beta 1$-integrin intracellular trafficking. For this purpose, we designed a recombinant DsRed $_{2}$ tagged $\beta 1$-integrin (DSR- $\beta 1$-ITG) that was checked for correct mRNA transcription (Figure 5A) as well as protein expression (Figure $5 \mathrm{~B}$ ) in plasmidtransfected thyroid carcinomas. Figure 5C shows that the recombinant DsRed2-tagged $\beta 1$-integrin exhibited a consistent localization in transfected cells, especially forming clusters at the adhesion sites. Recombinant $\beta 1$-integrin cluster dynamics was then monitored
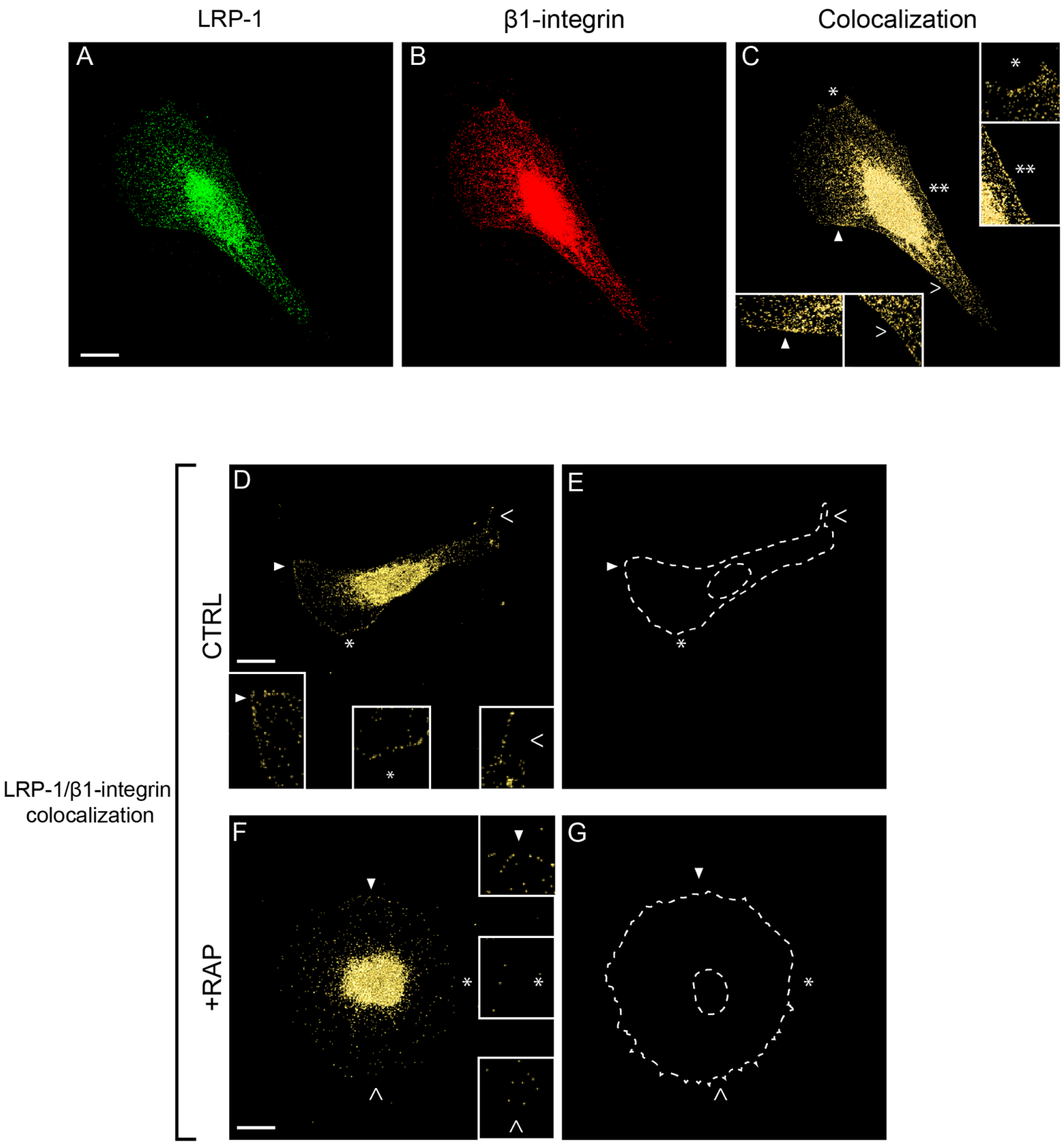

Figure 4: Endogenous $\beta 1$-integrin colocalizes with LRP-1 in FTC-133 cells. FTC-133 cells were seeded onto $1 \%$ gelatincoated coverslips and allowed to grow $24 \mathrm{~h}$ in control conditions (A to E, CTRL) or under $500 \mathrm{nM}$ RAP treatment during $1 \mathrm{~h}(\mathbf{F}-\mathbf{G},+\mathrm{RAP})$. Cell labeling was conducted using Alexa Fluor 488 for LRP-1 $\alpha$-chain (A) and Alexa Fluor 568 for $\beta 1$-integrin (B) both validated for immunofluorescence (data not shown) before confocal microscopy analysis. Colocalization between LRP-1 and $\beta 1$-integrin is represented in yellow in C, D and F panels. Two-fold enlargements (insets) are indicated by empty and full arrowheads or by white stars, highlighting cell membrane regions ( $\mathbf{C}$ to $\mathbf{G})$. $\mathbf{E}$ and $\mathbf{G}$ were used as patterns to represent cell shapes of $\mathbf{D}$ and $\mathbf{F}$, respectively. Images were treated with AMIRA software and correspond to isosurface representations, as indicated in Materials and Methods. Bars: $10 \mu \mathrm{m}$. 


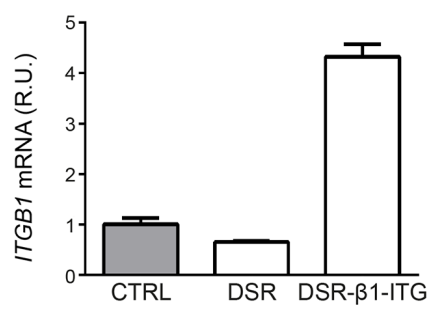

C
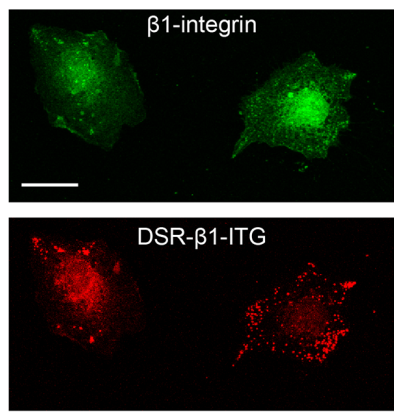

D
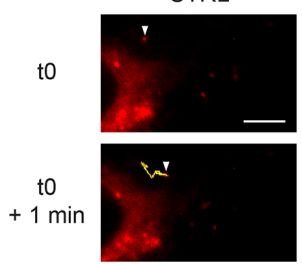

$2 \stackrel{\text { to }}{\mathrm{min}}$

$+2 \mathrm{~min}$

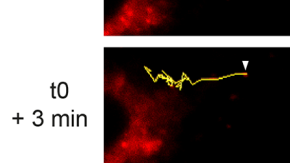

to
$+4 \min$

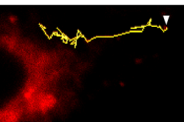

to
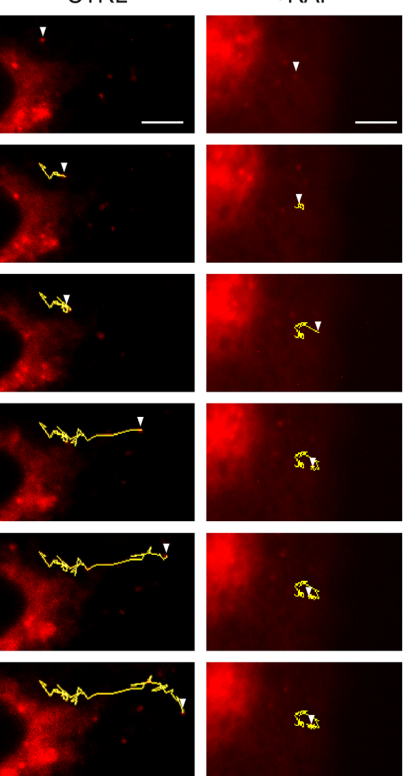

B
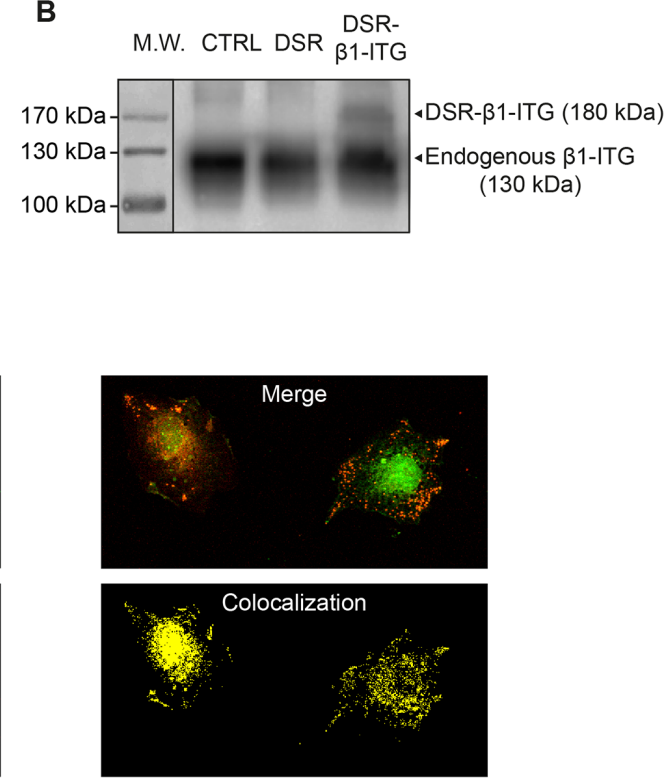

E
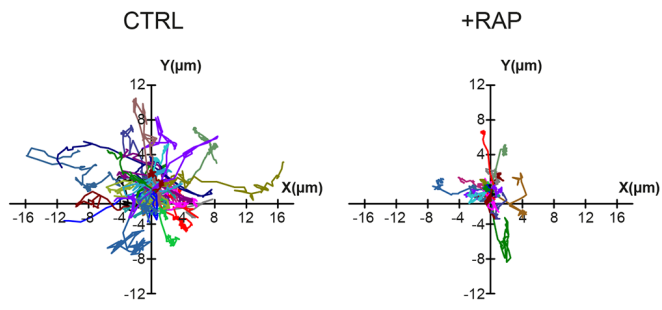

$\mathbf{F}$
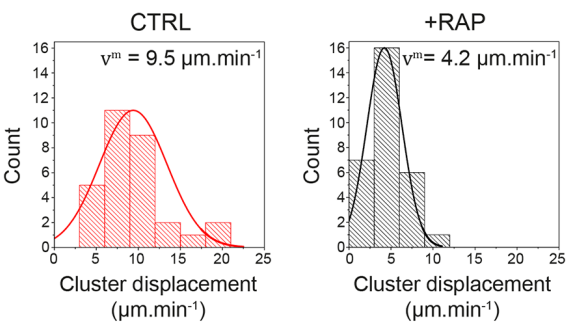

$\left(\mu \mathrm{m} \cdot \mathrm{min}^{-1}\right)$

Figure 5: The intracellular trafficking of $\beta 1$-integrin clusters is under LRP-1 control. (A) Total RNAs were purified from FTC133 cells transfected with either a DSR ${ }_{2}$-control plasmid (DSR) or the DsRed ${ }_{2}-\beta 1$-integrin encoding plasmid (DSR- $\beta 1$-ITG). ITGB 1 mRNA expression was quantified using real-time RT-PCR and expressed as relative units (R.U.). RPL32 and RS18 were used for normalization. Non-transfected cells (CTRL) served as a reference set to 1. (B) Recombinant DsRed ${ }_{2}-\beta 1$-integrin (DSR- $\beta 1$-ITG) expression was assessed by SDS-PAGE immunoblotting using anti- $\beta 1$-integrin (M-106) antibodies. While endogenous $\beta 1$-integrin migrates around $130 \mathrm{kDa}$ (CTRL and DSR), an expected shift to $180 \mathrm{kDa}$ was observed for the DSR- $\beta 1$-ITG recombinant product (DSR- $\beta 1-\mathrm{ITG}$ ). Protein ladder was indicated on the left of the SDS-PAGE. (C) FTC-133 cells were seeded onto 1\% gelatin-coated coverslides and then allowed to grow for $24 \mathrm{~h}$ before being transfected with DsRed ${ }_{2}-\beta 1$-integrin plasmid (DSR- $\beta 1$-ITG, red). After $24 \mathrm{~h}$, cells were labeled with Alexa fluor 488 for endogenous $\beta 1$-integrin (green). Merged image and colocalization signal were presented in right panels. Bar: $10 \mu \mathrm{m}$. (D) FTC-133 cells were seeded onto $1 \%$ gelatin coated labtek-I and then transfected with DsRed ${ }_{2}-\beta 1$-integrin plasmid (DSR- $\beta 1$-ITG). Cells were maintained under control conditions (CTRL) or treated with $500 \mathrm{nM}$ RAP (+RAP) while video microscopy images were taken every $4 \mathrm{~s}$ over 5 min. Trajectories for one representative DSR- $\beta 1$-ITG cluster in both conditions are represented in yellow. White arrowhead represents the position of DSR- $\beta 1$-ITG cluster from $t=0$ (i.e. $10 \mathrm{~min}$ after RAP addition) to $t=5 \mathrm{~min}$. Bars: $5 \mu \mathrm{m}$. (E) Trajectories of DsRed $-\beta 1$-integrin clusters obtained under control conditions (CTRL) or $500 \mathrm{nM}$ RAP treatment (+RAP) are represented through $X Y$ axes $(\mathrm{n}=28$ and $\mathrm{n}=29$, respectively; 4 independent experiments). (F) Diagrams represent the repartition of DsRed ${ }_{2}-\beta 1$-integrin clusters displacement speed under control (CTRL) or $500 \mathrm{nM}$ RAP treatment (+RAP) conditions. $\mathrm{v}^{\mathrm{m}}$ represents the average speed of DSR- $\beta 1$-ITG clusters in each condition. Overlay curve is the normalized Gaussian curve deduced from our results. 
by video microscopy (Figure $5 \mathrm{D}$ to $5 \mathrm{~F}$ ). In control conditions, $\beta 1$-integrin clusters exhibited large amplitude motions especially along a linear and straightforward displacement (Figure 5D and 5E, left panels). On the contrary, $\beta 1$-integrin clusters turned around a single point and progressively slowed down to immobilization under RAP-mediated LRP-1 functional inhibition (Figure 5D and 5E, right panels). Accordingly, we found that RAP treatment induced a two-fold decrease in the motion velocity of $\beta 1$-integrin clusters (Figure 5F).

\section{ß1-integrin addressing to early endosomes occurs in a LRP-1-dependent manner}

As $\beta 1$-integrin trafficking occurs under LRP-1 dependence (Figure 5), we sought to determine whether LRP- 1 mediates $\beta 1$-integrin internalization. We investigated $\beta 1$-integrin uptake by using a previously validated endocytosis assay [37]. This approach requires labeling of cell surface proteins using a non-membrane-permeating sulfo-NHS-LC-biotin at $4^{\circ} \mathrm{C}$, then moving to a permissive temperature for endocytosis $\left(37^{\circ} \mathrm{C}\right)$. Cell surface protein biotinylation as well as efficiency of biotin stripping with glutathione were controlled (Figure 6A, left panel). In this assay, we determined that $83 \%$ of the biotinylated $\beta 1$-integrin was internalized after $10 \mathrm{~min}$ at $37^{\circ} \mathrm{C}$ in control conditions. Results from Figure 6A (middle panel) indicate that $\beta 1$ integrin internalization was decreased by about 2 -fold and 2.5-fold when LRP-1-mediated endocytosis was inhibited by RAP antagonist or using R2629 blocking antibodies, respectively [38, 39]. Consistently, the uptake of $\beta 1$-integrin was also partially inhibited under LRP-1 siRNA silencing (Figure 6A, right panel). To investigate this further, Rab5a labeling was performed to examine $\beta 1$-integrin distribution within early endosome vesicles (Figure 6B). Confocal imaging allowed analysis of $\beta 1$-integrin-containing early endosomes (Figure 6B, yellow spots in right panels) as well as endosome vesicles that did not contain $\beta 1$ integrin (Figure 6B, blue spots in right panels). In control conditions, $\beta 1$-integrin appeared to be highly internalized, particularly from the migrating front (Figure 6B, upper panel). Distribution of $\beta 1$-integrin into early endosomes was drastically decreased when antagonizing LRP-1-mediated endocytosis with RAP (Figure 6B, middle panel) or using R2629 blocking antibodies (Figure 6B, bottom panel). Quantitative analysis confirmed these observations as the percentage of early endosomes positive for $\beta 1$-integrin was reduced compared to control cells by $25 \%$ and $36 \%$ under RAP or R2629 treatment, respectively. In accordance with the foregoing results, $\beta 1$-integrin internalization was reduced by $31 \%$ in LRP-1-silenced cells as compared to control cells transfected with nontargeting siRNA (Figure 6C).

\section{LRP-1 does not route $\beta 1$-integrin toward lysosomes and mediates its recycling back to the cell surface}

Next we examined whether internalized $\beta 1$-integrin clusters were delivered to lysosomes in a LRP-dependent manner. For this purpose, cells were labeled using anti$\beta 1$-integrin antibodies following infection of a fusion construct of LAMP-1 (lysosomal-associated membrane protein-1) and Tag-RFP (red fluorescent protein) (Figure $7)$. Interestingly, we observed that $59 \%$ of lysosomes contained $\beta 1$-integrin in control tumor cells (Figure 7, upper panel). Contrary to that has been observed regarding endosome vesicles (Figure 6B), LRP-1 blockade using either RAP or R2629 treatment did not significantly affect the percentage of $\beta 1$-integrin-containing lysosomes, nor the apparent intracytoplasmic distribution of such vesicles (Figure 7, middle and bottom panels). No other lysosomal features (i.e. number, size) appeared significantly altered by such treatments (data not shown). These results indicate that LRP-1-mediated endocytosis of $\beta 1$-integrin is not routed toward lysosomes for degradation. To assess the fate of $\beta 1$-integrin internalized by LRP-1, we carried out immunofluorescence experiments using double labeling with antibodies raised against $\beta 1$-integrin and Rab11, a marker of recycling endosomes [40]. In control conditions, colocalization of active (9EG7) as well as inactive (Mab13) $\beta 1$-integrin with Rab11 was mainly observed at the perinuclear area and also at the migration front and the trailing edge of the cell (Figure 8). Such a colocalization signal was drastically decreased under RAP conditions for both active (upper panel) and inactive (lower panel) $\beta 1$-integrin. These data confirmed that the fraction of $\beta 1$ integrin internalized by LRP-1 was mainly addressed to the endosomal trafficking pathway for recycling.

\section{DISCUSSION}

In this study, we highlighted that the endocytic receptor LRP-1 establishes tight molecular connections with $\beta 1$-integrin isoform at the cell surface of thyroid carcinoma cells. In a tumor context, we here provide evidence that the LRP-1/ $\beta 1$-integrin complex constitutes an endocytic complex able to route $\beta 1$-integrin to early endosomes, then to recycling Rab11-containing vesicles, while avoiding lysosome targeting. We thus identified a new molecular process that regulates the cell surface levels of $\beta 1$-integrin and that directs it to the endosomal trafficking pathway in thyroid tumor cells.

Our findings provide new mechanistic insights that help to improve the understanding of LRP-1 contribution in cancer cells. Although long debated, it is now well established that LRP-1 may control critical events influencing tumor cell attachment, spreading, migration and invasion $[20,21,24,33,41]$. LRP1 gene silencing in cancer cells was indeed found to accelerate 
A

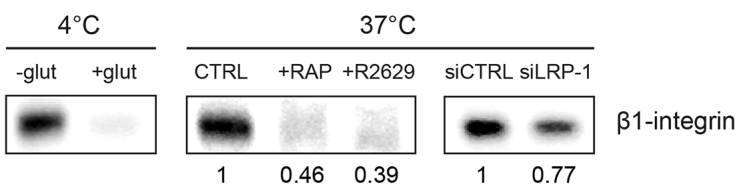

B
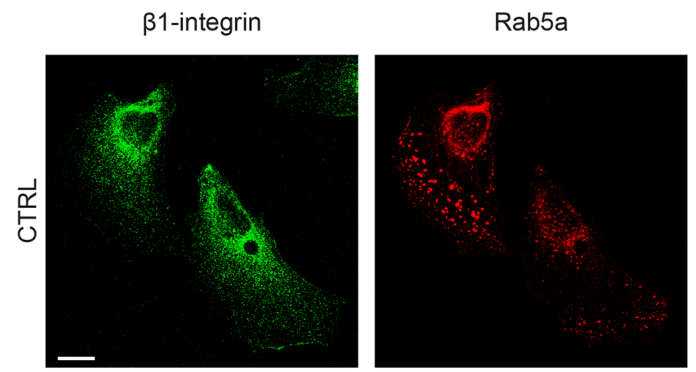

Endosomal vesicles
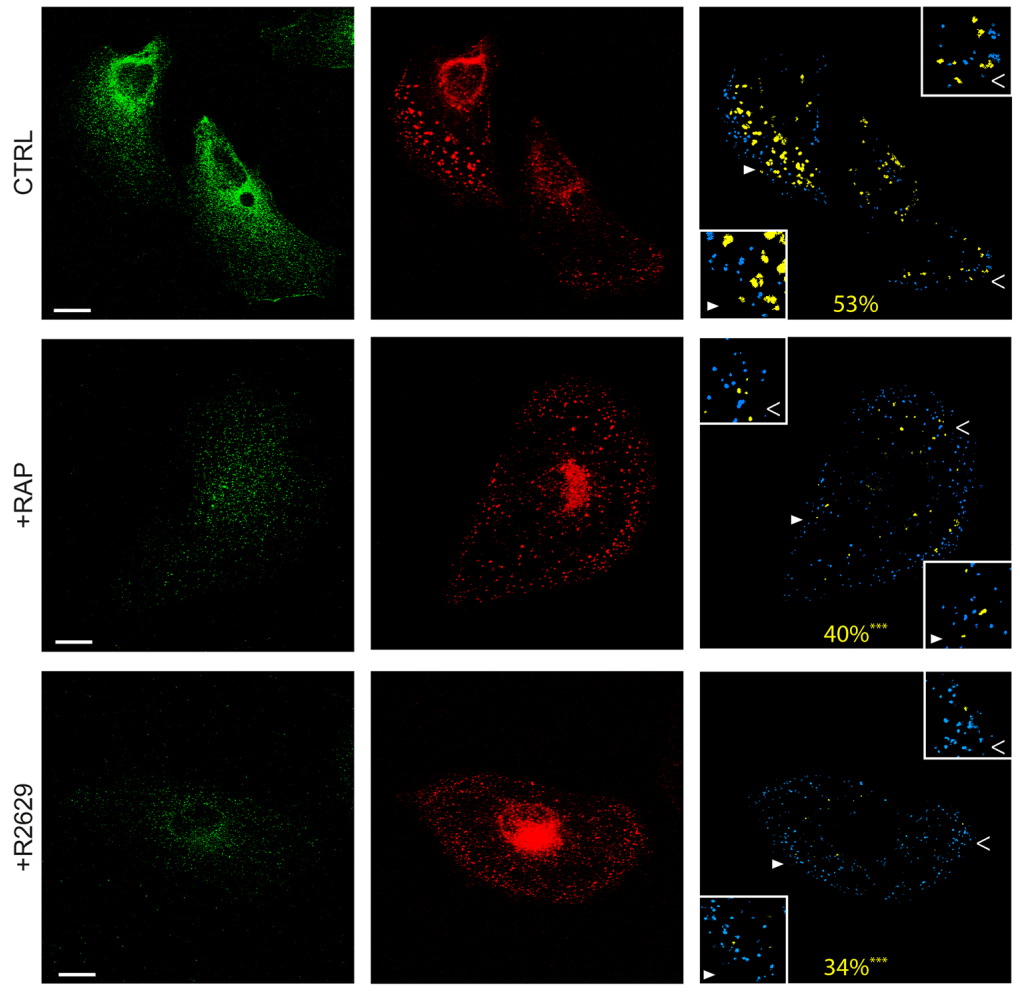

C
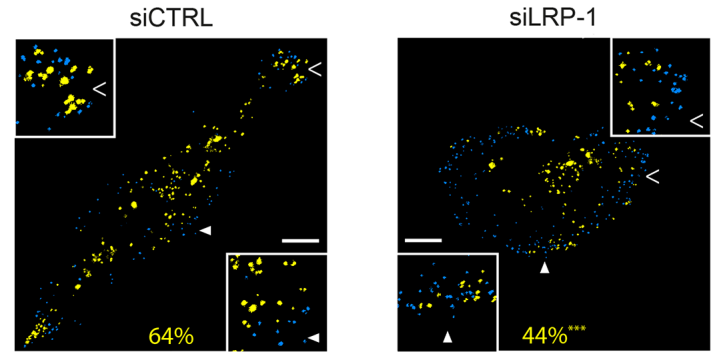

Figure 6: LRP-1 mediates $\beta 1$-integrin endocytosis in thyroid tumor cells. (A) FTC-133 cells were plated onto $1 \%$ gelatincoated wells and then allowed to grow for $1 \mathrm{~h}$ under non-treated conditions (CTRL), $500 \mathrm{nM}$ RAP (+RAP) or $2.5 \mu \mathrm{g} \cdot \mathrm{mL}^{-1}$ R2629 blocking antibody (+R2629), or either transfected with non-silencing siRNA (siCTRL) or siRNA targeting LRP1 (siLRP-1). Internalization assay was conducted as described in Materials and Methods section. The amount of internalized $\beta 1$-integrin was analyzed by immunoblotting using M-106 antibodies $\left(37^{\circ} \mathrm{C}\right.$, middle and right frames). Left frame $\left(4^{\circ} \mathrm{C}\right)$ serves to control $\beta 1$-integrin binding to the cell surface (-glut, lane 1) and glutathione efficiency (+ glut, lane 2). Numbers under the immunoblots indicate the average fold induction by comparison with the CTRL (middle panel) or siCTRL (right panel) cells, and were calculated from three distinct experiments. (B) FTC-133 cells were cultured onto $1 \%$ gelatin-coated coverslips and maintained under control conditions (CTRL), $500 \mathrm{nM} \mathrm{RAP}$ treatment (+RAP) or 2.5 $\mu \mathrm{g} . \mathrm{mL}^{-1} \mathrm{R} 2629$ blocking antibody (+R2629). Then, cells were labeled with Alexa Fluor 488 for $\beta 1$-integrin (left panel) and infected with endotracker for Rab5a staining (middle panel) before confocal microscopy analysis. On the right panel, endosomal vesicles containing no $\beta 1$-integrin are represented in blue while $\beta 1$-integrin-containing-endosomal vesicles are represented in yellow. The average percent of early-endosomes containing $\beta 1$-integrin is indicated in yellow. Statistical analysis was conducted on endosomal vesicles from 60 to 200 voxels (***, P $<0.001$; as compared to CTRL). Insets (full and empty white arrowheads) highlight representative endosomal vesicles in each condition (2-fold enlargement). Bars: $10 \mu \mathrm{m}$. (C) The same experimental procedure and statistical analysis as that detailed above (in B) were carried out on FTC-133 cells either transfected with non-silencing siRNA (siCTRL) or siRNA targeting LRP1 (siLRP-1). Bars: $10 \mu \mathrm{m}$. 
cell attachment, provoke major actin-cytoskeleton rearrangements and induce the accumulation of abundant talin-containing focal adhesion complexes [20, 34]. Focal adhesions are large complexes establishing a link between cell actin cytoskeleton and the ECM. The cytoplasmic side of these complexes consists in an association of many structural, enzymatic and adapter proteins including talin, paxillin and FAK [42]. LRP-1 was shown to decrease talin levels and distribution in cancer cells and is required for paxillin and FAK association within focal adhesions $[20,33]$. This sustains the existence of a close functional relationship between LRP-1 and focal adhesions. Orr and collaborators consistently described LRP-1 as a coreceptor for calreticulin which is necessary to stimulate reorganization and disassembly of focal adhesions in endothelial cells in response to the hep I sequence of thrombospondin-1 [29]. It was therefore proposed that the ability of LRP-1 to mediate endocytosis of transmembrane
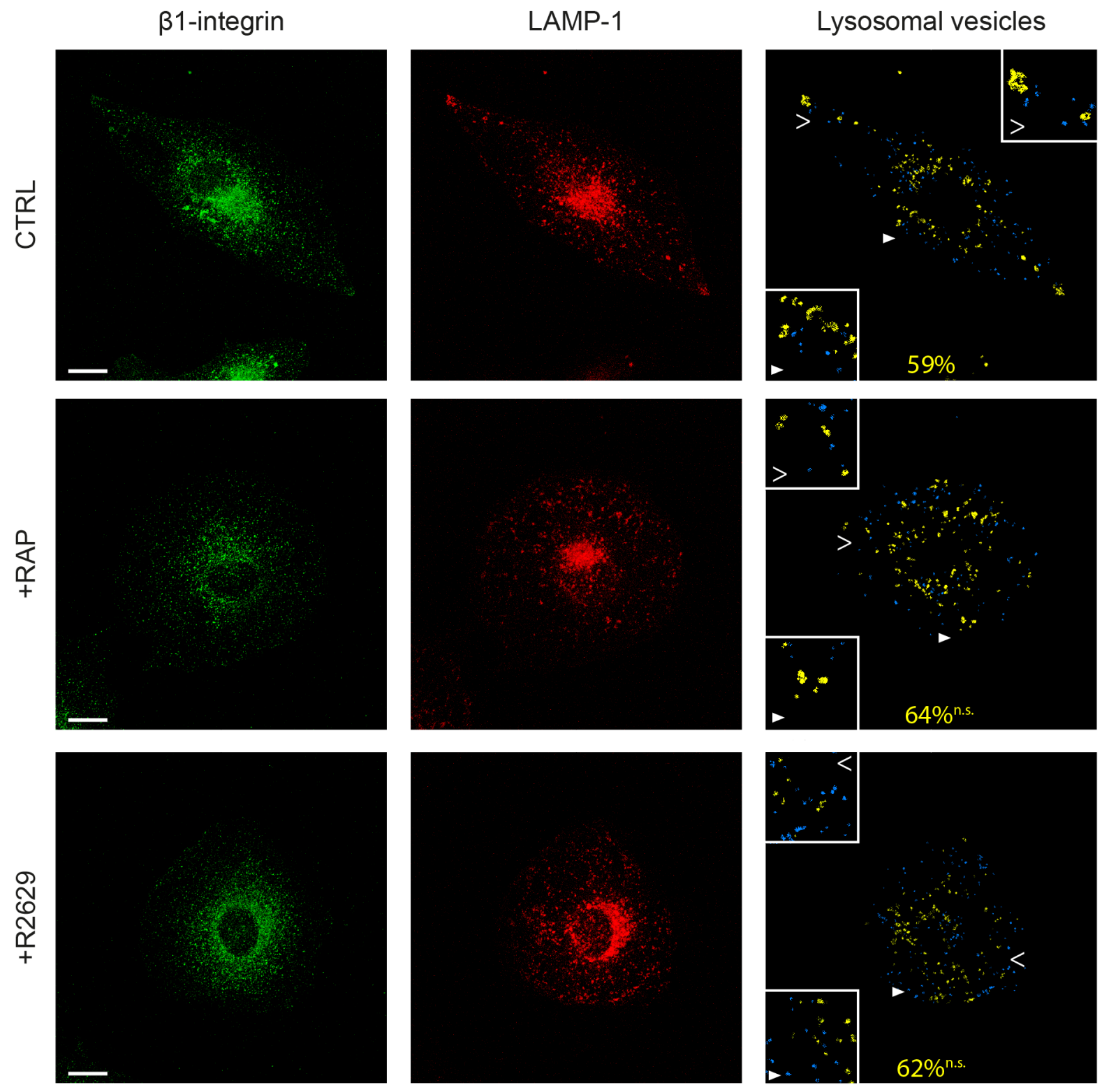

Figure 7: LRP-1 does not address $\boldsymbol{\beta} 1$-integrin to lysosomes. FTC-133 cells were plated onto $1 \%$ gelatin coated coverslides and then maintained during $1 \mathrm{~h}$ under control conditions (CTRL), $500 \mathrm{nM}$ RAP (+RAP) or $2.5 \mu \mathrm{g} \cdot \mathrm{mL}^{-1}$ R2629 antibody (+R2629) treatment. $\beta 1$-integrin staining with Alexa Fluor 488 (left panel) and infection with lysotracker for LAMP-1 (middle panel) were carried out before confocal microscopy analysis. On the right panel, lysosomes containing no $\beta 1$-integrin are represented in blue and $\beta 1$-integrin-containing lysosomes are represented in yellow. The average percentage of lysosomes positive for $\beta 1$-integrin is indicated in yellow. Statistical analysis was conducted on lysosomal vesicles from 60 to 200 voxels (n.s., not significant; as compared to CTRL). Cell areas indicated by full and empty white arrowheads highlighting representative lysosomes for each condition are proposed as 2-fold enlargement insets. Bars: $10 \mu \mathrm{m}$. 

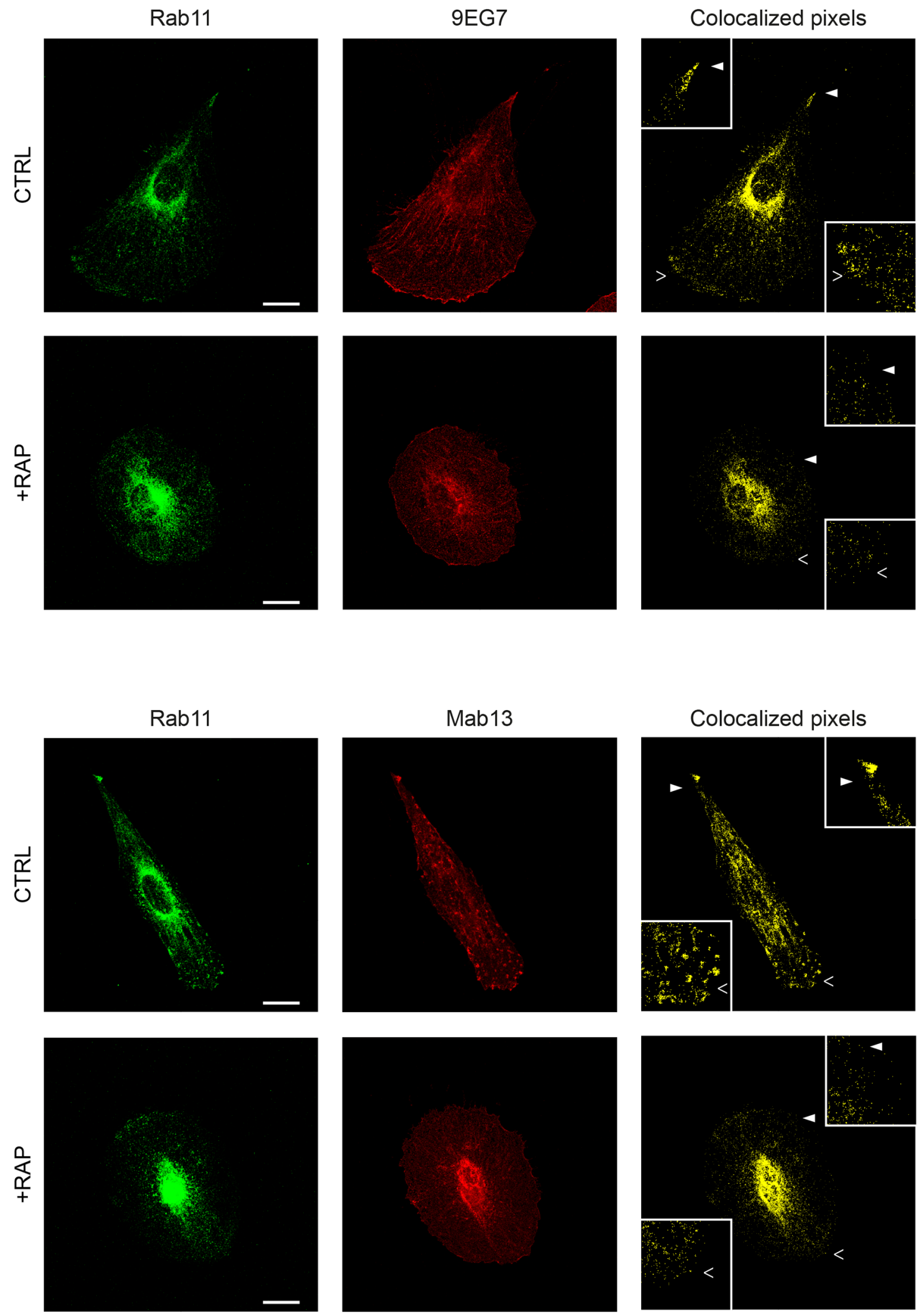

Figure 8: $\beta 1$-integrin recycling appears to be under LRP-1 dependence in thyroid tumor cells. FTC-133 cells were plated onto $1 \%$ gelatin coated coverslips, maintained under control conditions (CTRL) or $500 \mathrm{nM}$ RAP treatment (+RAP), and then stained with Alexa Fluor 488 for Rab11 (left panels) and Alexa Fluor 568 for active $\beta 1$-integrin (9EG7, upper panel) or inactive $\beta 1$-integrin (Mab13, lower panel) before confocal microscopy analysis. Colocalization between Rab11 and either active or inactive $\beta 1$-integrin is represented in yellow (colocalized pixels: right panel). 2-fold enlargements (insets) are indicated by full and empty white arrowheads. Bars: $10 \mu \mathrm{m}$. 
proteins may explain its role in coordinating the adhesiondeadhesion balance of cancer cells. Transmembrane integrins assure a direct link between proteins from the ECM and the cytoplasmic complex. Furthermore, integrins are well characterized for their central role in regulating cell adhesion and migration in both a physiological or tumor context [31, 32, 43]. For all these reasons, we are convinced that LRP-1-mediated internalization and recycling of $\beta 1$-integrin sheds new light on how LRP-1 contributes to focal adhesion dynamics and disassembly.

Until now, limited data existed in the literature regarding a close functional relationship between LRP-1 and integrins. Our data obtained from thyroid carcinoma cells clearly demonstrate that inhibition of LRP-1-dependent endocytosis by either RAP or RNA interference promotes a similar cell surface accumulation of both $\beta 1$ - and $\beta 2$-integrin. Considering $\beta 2$-integrin, it is not particularly surprising because LRP-1 specifically recognizes $\beta 2$-integrin when associated with $\alpha \mathrm{M}$ isoform in macrophages $[44,45]$. It was also previously reported that down-regulation of LRP-1 impaired $\beta 2$-integrindependent adhesion of leukocytes to endothelial cells [35]. For $\beta 1$-integrin, recent work described that accumulation of LRP-1 at the plasma membrane correlated with elevated levels of cell surface $\beta 1$-integrin in mouse embryonic fibroblasts harboring a knock-in replacement of the distal NPxY motif of LRP-1 [46]. In this work, we have shown that LRP-1 tightly binds with both active and inactive isoforms of $\beta 1$-integrin (Figure 2) and that both isoforms can be directed via LRP-1 to endosomal trafficking (Figure 8). This point deserves to be noted because previous work reported distinct subcellular localization and divergent trafficking routes between active and inactive $\beta 1$ integrin in breast, prostate and lung cancer cells [36]. Our results demonstrate that both $\beta 1$-integrin conformations colocalize within Rab11 vesicles, suggesting that both active and inactive conformations undergo common recycling early steps in thyroid carcinomas.

Further, we observed that LRP-1-mediatedendocytosis did not route $\beta 1$-integrin toward lysosomes (Figure 7). Integrin endocytosis was recently shown to facilitate endosomal FAK signaling which mainly contributes to suppress anoikis and support anchorageindependent growth of cancer cells [47]. From our results, we believe that it is likely that LRP-1 plays a role in such cancer-related processes by directing and maintaining $\beta 1$ integrin to the endosomal traffic. This is highly coherent with our previous findings stressing the role of LRP-1 in sustaining FAK activation [20,33]. It was reported that SNX17 (sorting nexin-17) acts as a sorting signal for $\beta 1$ integrin, directly addressing it toward a Rab11 recycling loop and therefore avoiding lysosomal degradation [48, 49]. Remarkably, SNX17 is also known to bind LRP-1 to facilitate its recycling back to the plasma membrane $[50,51]$ thus making it a likely molecule involved in the recycling pathway of LRP-1 complexed with $\beta 1$-integrin.
In thyroid cancer cells, the LRP-1/ $\beta 1$-integrin biomolecular complex was rather observed at the migration front and along the cell body where retraction fibers occur. This is in line with a contribution of LRP1 in focal adhesion distribution and dynamics [34, 46]. Other studies have described a preferential localization of LRP-1 at the same sites in invasive cancer cells [22, 28]. The LRP-1/ $\beta 1$-integrin complex was also found widely in the perinuclear and the juxtamembrane areas, consistent with its maintenance during internalization and traffic in the cytoplasm. Using a video microscopy approach, we showed that trajectories of $\beta 1$-integrin clusters were sharply modified when the LRP-1-mediated endocytosis was antagonized, turning out from a straightforward direction to circular motions centered on a single point without any distinctive linear direction (Figure 5). This provides new molecular data regarding integrin traffic.

Using truncated mini-receptors, we demonstrated that the ligand-binding domains II and IV of the LRP-1 $\alpha$-chain were required for $\beta 1$-integrin binding (Figure 2). This explains why RAP treatment significantly decreased the LRP-1/ $\beta 1$-integrin complex formation and impaired its distribution and trafficking (Figures 4-6 and 8). This observation seems to contradict recent work reported by Rabiej and collaborators describing the crucial role of the intracellular $\beta$-chain of LRP-1 in integrin ligation [46]. To explain this, we suggest that LRP-1 and $\beta 1$ integrin may not interact in a direct fashion but rather within a biomolecular structure involving other binding partners, which would be highly dependent of the cellular microenvironment. Indeed, this is supported by surface plasmon resonance experiments that failed to reveal direct connections between these two proteins (data not shown). Interestingly, the formation of this complex is not specific of thyroid carcinoma and occurs in many tumor and nontumor cells (Figure 3), probably depending at least to the amount and localization of LRP-1 at the cell surface.

$\beta 1$-integrin is able to dimerize with 12 different $\alpha$ partners [52] and among these heterodimers, several are known to promote tumor progression such as $\alpha 2 \beta 1$ [53], $\alpha 3 \beta 1$ [54], $\alpha 5 \beta 1[55,56]$ or $\alpha v \beta 1$ [57]. It is known that $\beta 1$-integrin association with $\alpha 5$-integrin is recycled through Rab11 vesicles to increase focal adhesion turnover or to influence cell spreading and migration [58]. Despite expression of $\alpha 2, \alpha 3, \alpha 5$ and $\alpha v$-integrin in our experimental model, we did not identify a preferential $\alpha$-subunit associated with $\beta 1$-integrin during the LRP1 -mediated endocytosis. Furthermore, no $\alpha$-integrin was found accumulated at the cell-surface under LRP-1 antagonism or silencing (Figure 1). We do not believe that LRP-1 could mediate endocytosis of $\beta 1$-integrin without an $\alpha$ isoform counterpart. We rather speculate that under LRP-1 inhibition, accumulated $\beta 1$-integrin at the plasma membrane was redistributed between distinct $\alpha$ isoforms making difficult the detection of a significant change in $\alpha / \beta$-integrin levels. 
It is worth noting that the amount of $\beta 1$-integrin at the plasma membrane is only enhanced by about $25 \%$ under LRP-1 inhibition (Figure 1). This is in concordance with the $25 \%$ to $36 \%$ decrease in the number of $\beta 1$ integrin-containing early endosomes observed under LRP1 blockade (Figure 6). This means that only one third of the $\beta 1$-integrin pool is internalized in a LRP-1-dependent manner. This appears relatively low compared to what was reported for other membrane-anchored partners of LRP1 involved in adhesion, such as CD44 or uPAR [10, 28, 59]. This can be explained by a differential availability of these receptors on the plasma membrane. Of note, LRP1 was reported to promote $\beta 1$-integrin maturation and to contribute to increase its amount at the cell surface [60]. Therefore, this may interfere with our observations and may explain why only low accumulation of $\beta 1$-integrin was detected at the plasma membrane under LRP-1 blockade or silencing.

We believe that the ability of LRP-1 to mediate the uptake and recycling of $\beta 1$-integrin has consequences on tumor progression beyond the regulation of cell adhesion, migration and invasion. It has been shown that $\beta 1$-integrin expression dictates radiotherapy resistance in head and neck cancer [61] and drives lung and breast cancer cell resistance to erlotinib and lapatinib, respectively $[62,63]$. Particularly, $\alpha 2 \beta 1$ integrin was characterized as an important survival pathway in doxorubicin-induced apoptosis [64]. $\alpha 5 \beta 1$ heterodimers were further found to support glioma resistance to temozolomide and is being considered as a therapeutic target for high-grade brain tumors [65]. Targeting $\beta 1$-integrin/mTOR pathway was also suggested as a therapeutic strategy to overcome chemotherapy resistance to docetaxel for the treatment of gliomas [66].

Overall, deciphering the mechanisms of LRP1-dependent endocytosis is key for increasing our knowledge on how $\beta 1$-integrin expression, localization and traffic is regulated in tumor cells. By achieving this we have enabled others to consider alternative mechanisms whilst developing alternative drugs targeting $\beta 1$-integrin.

\section{MATERIALS AND METHODS}

\section{Antibodies and recombinant proteins}

Mouse anti-LRP-1 $\alpha$-chain (clone 8G1) and $\beta$-chain (clone 5A6) monoclonal antibodies were from Calbiochem (San Diego, CA, USA) and rabbit LRP$1-\beta$-chain antibody (clone EPR3724) was from Abcam (Cambridge, UK). Nonreactive rabbit (EPR25A) and mouse (K1814) IgGs used as negative control for immunoprecipitation were from Abcam and Santa Cruz Biotechnology (Heidelberg, Germany), respectively. Blocking LRP-1 polyclonal antibody (R2629) was a generous gift from Dr. D.K. Strickland (Department of Surgery, University of Maryland School of Medicine, Baltimore, MD, USA) [38]. Anti- $\beta 1$-integrin antibodies were purchased from Abcam (mouse, clone P4G11), Santa Cruz Biotechnology (rabbit, M106) or BD Pharmingen (San Jose, CA, USA) (rat, clone 9EG7 and clone Mab13). Anti-Rab11 (mouse, 47) antibody was purchased from Merck Millipore (Billerica, MA, USA). Alexa Fluor 488, Alexa Fluor 568, Alexa Fluor 647, Hoechst 33342 and FluorSave Reagent were from Thermofisher (Waltham, MA, USA). Anti-hemagglutinin (anti-HA) tag antibody (rabbit, C29F4) was from Cell Signaling (Danvers, MA, USA) and anti-actin (goat, I-19) antibody was purchased from Santa Cruz Biotechnology. FITC-labelled $\alpha 2$-macroglobulin was purchased from BioMac (Leipzig, Germany). Histidinetagged RAP was purified as previously described [28] and used to antagonize LRP-1-dependent endocytosis as previously reported $[28,33]$.

\section{DNA constructs}

The HA-tagged mini-receptors derived from LRP-1 were generated as described elsewhere [28]. Briefly, the SPCT (SP: signal peptide; CT: C-terminal) mini-receptor only contains LRP-1 $\beta$-chain, whereas DII and DIV molecular constructs respectively encompass the second and fourth ligand binding domains of LRP-1. The mammalian expression vector encoding the chimeric human $\beta 1$-integrin DsRed $_{2}$ (DSR- $\beta 1-I T G$ ) was generated as follows: a cDNA fragment coding for the full-length human $\beta 1$-integrin was amplified from clone IRATp970E0719D (ImaGenes, Germany) with the primers 5'-GGTAGCTAGCATGAAT TTACAACCAATTTTCTGG-3' and 5'-CCGCTCGAGTT TTCCCTCATACTTCGGATTG-3'. After NheI and XhoI digestion, the PCR product was inserted into pcDNA3.1 vector coding for the tandem dimer of DsRed, tdimer2, as previously described [67]. The cDNA construct was then sequenced and the chimeric protein DSR- $\beta 1-I T G$ has a theoretical molecular weight of $143 \mathrm{kDa}$. Considering posttranslational glycosylations, the expected molecular weight on SDS PAGE is about $180 \mathrm{kDa}$.

\section{Cell culture and transfection}

Human follicular thyroid carcinoma cells (FTC133 ; ECACC 94060901) were grown in Dulbecco's modified Eagle medium (DMEM)-Ham's F-12 medium (Dutscher, Brumath, France) supplemented with 10\% fetal bovine serum (FBS), as previously described [59]. MDAMB-231 (human breast cancer cells), COS-7 (kidney fibroblasts) and primary dermic fibroblast were cultured in DMEM plus 10\% FBS. U87 (human glioblastoma cells) and MNT-1 (human melanoma cells) were grown in Minimum Essential Media (MEM, Dutscher) supplemented with $10 \%$ and $20 \%$ FBS, respectively. HUVECs (human umbilical vein endothelial cells) were cultured in complete endothelial growth medium (EGM-2, Lonza). FTC-133 cells were transiently transfected with 
LRP-1-derived mini-receptors or DSR- $\beta 1$-ITG encoding plasmid using JetPEI reagent (Polyplus Transfection, Illkirch, France) according to manufacturer's instructions. LRP-1 knockdown was achieved by RNA interference using a previously validated siRNA approach [20]. LRP-1 siRNA as well as non-targeting siRNA used as controls were purchased from Dharmacon (Lafayette, CO, USA) and transiently transfected using Lipofectamine 2000 (Invitrogen, Carlsbad, CA, USA), as reported [28].

\section{Integrin antibody array}

The $\alpha / \beta$-integrin-mediated cell adhesion array kit (ECM532, Merck Millipore) was used in order to assess the presence of specific integrin subunits at the cell surface. Experiments were performed as indicated by the manufacturer on untreated, RAP-treated and siRNAtransfected FTC-133 cells.

\section{RNA isolation and real-time PCR}

Total mRNA were extracted using TRIzol reagent (Thermofisher), isolated from other cellular materials by chloroform/isoamyl alcohol (24:1) precipitation before centrifugation $\left(12,000 \times \mathrm{g}, 4^{\circ} \mathrm{C}, 15 \mathrm{~min}\right)$, as described elsewhere [34]. $250 \mathrm{ng}$ total mRNA were reversetranscribed using VERSO cDNA kit (Thermofisher) according to the manufacturer instructions. Real-time PCR was then performed using an Absolute SYBR Green Rox mix (Thermofisher) and a CFX 96 real time PCR detection system (Bio-Rad, Hercules, CA, USA). The cycle threshold $(\mathrm{Ct})$ values were recorded using Bio-Rad CFX Manager 3.0 software (Bio-Rad) [34]. PCR primers were synthesized by Eurogentec (Liege, Belgium) as follow (5'-3'): for LRP1: GCTATCGACGCCCCTAAGAC and CGCCAGCCCTTTGAGATACA; for ITGB1: CA TCTGCGAGTGTGGTGTCT and GGGGTAATTTGTC CCGACTT; for RS18: GCAGAATCCACGCCAGTACAA and GCCAGTGGTCTTGGTGTGCT; for RPL32: CATTGGTTATGGAAGCAACAAA and TTCTTGGA GGAAACATTGTGAG.

\section{Immunofluorescence and internal vesicles labeling}

FTC-133 cells were seeded onto $1 \%$ gelatin-coated glass slides for $24 \mathrm{~h}$ at $37^{\circ} \mathrm{C}$ and then fixed in phosphatebuffered saline (PBS) containing 4\% paraformaldehyde for $15 \mathrm{~min}$ at room temperature. After three washes with ice-cold PBS, cells were incubated for $1 \mathrm{~h}$ in PBS containing $1 \%$ bovine serum albumin and then incubated overnight at $4{ }^{\circ} \mathrm{C}$ with primary antibodies raised against LRP-1 (clone 8G1), $\beta 1$-integrin (M-106, clone 9EG7 or Mab13) or Rab11 (clone 47). Then, slides were washed five times with ice-cold PBS and cells were incubated with secondary antibodies conjugated to Alexa Fluor
488 (1/500), Alexa Fluor 568 (1/500) or Alexa Fluor 647 $(1 / 500)$ during $2 \mathrm{~h}$ at room temperature. For endosomes and lysosomes labelling, living cells were incubated overnight at $37^{\circ} \mathrm{C}$ with CellLight Endosome-RFP or CellLight Lysosome-RFP (Thermofisher) according to the manufacturer instructions, and then fixed in $4 \%$ paraformaldehyde for $15 \mathrm{~min}$ at room temperature.

\section{Total protein extraction and western blot analysis}

Whole-cell extracts were prepared by scraping cells in ice-cold lysis buffer containing $10 \mathrm{mM}$ Tris$\mathrm{HCl}, \mathrm{pH}$ 7.5, $150 \mathrm{mM} \mathrm{NaCl}, 5 \mathrm{mM}$ EDTA, 1\% Triton $\mathrm{X}-100$, supplemented with proteinase inhibitor cocktail (Sigma-Aldrich, Saint-Louis, MO, USA). Samples were vortexed and remaining pellet was separated by centrifugation $\left(10,000 \times g\right.$ for $20 \mathrm{~min}$ at $\left.4^{\circ} \mathrm{C}\right)$ and then discarded. Protein concentration was quantified using the BCA method (Interchim, Montluçon, France). Proteins were separated by sodium dodecyl sulfate-polyacrylamide gel electrophoresis (SDS-PAGE), transferred onto a nitrocellulose membrane (Amersham Biosciences, Little Chalfont, UK), and incubated $16 \mathrm{~h}$ at $4^{\circ} \mathrm{C}$ under gentle agitation with anti-LRP-1 $\alpha$-chain (1 $\left.\mu \mathrm{g} \cdot \mathrm{mL}^{-1} ; 8 \mathrm{G} 1\right)$, anti-LRP-1 $\beta$-chain $\left(1 \mu \mathrm{g} . \mathrm{mL}^{-1}, 5 \mathrm{~A} 6\right.$ or EPR3724), anti$\beta 1$-integrin (1 $\mu$ g.mL $\mathrm{mL}^{-1}$ M-106) or anti- $\beta$-actin $(0.2$ $\mu \mathrm{g} . \mathrm{mL}^{-1}$; I-19). Membranes were then incubated for $2 \mathrm{~h}$ at room temperature with the corresponding secondary fluorescence-coupled antibody. Tris-buffered saline (TBS)Tween buffer was used for all washes. Immunoreactive bands were revealed using the Odyssey-FC system (Licor, Lincoln, NE, USA). Immunoblots presented are representative of at least three separate experiments.

\section{Cell surface protein isolation}

FTC-133 cells were washed twice with ice-cold PBS, and then cell surface proteins were biotinylated with PBS containing $0.5 \mu \mathrm{g} . \mathrm{mL}^{-1}$ of EZ-Link sulfo-NHSLC-biotin (Thermofisher) for $30 \mathrm{~min}$ at $4^{\circ} \mathrm{C}$. After three washes, cells were incubated with $100 \mathrm{mM}$ glycine for $30 \mathrm{~min}$ at $4^{\circ} \mathrm{C}$ in order to limit nonspecific binding. Cells were washed three times in ice-cold lysis buffer before protein extraction. Cell extracts were pelleted at 10,000 $\times$ $g\left(20 \mathrm{~min}, 4^{\circ} \mathrm{C}\right)$ before protein quantification. Solubilized biotinylated proteins were then affinity purified using 40 $\mu \mathrm{l}$ of monomeric avidin-agarose beads (GE Healthcare, Chicago, IL, USA) incubated with $120 \mu \mathrm{g}$ of biotinylated proteins. Incubation was performed overnight at $4^{\circ} \mathrm{C}$ under gentle orbital agitation ( $5 \mathrm{rpm})$, and then followed by five washes in lysis buffer. For immunoblotting experiments, SDS-containing Tris-glycine buffer was added, and samples were heated at $100^{\circ} \mathrm{C}$ during $5 \mathrm{~min}$, centrifuged $\left(1000 \times g\right.$ for $2 \mathrm{~min}$ at $\left.4^{\circ} \mathrm{C}\right)$, and resolved by SDS-PAGE followed by immunoblotting analysis. 


\section{Immunoprecipitation}

Whole-cell extracts or plasma membrane extracts (corresponding to cell surface biotinylated proteins) were subjected to immunoprecipitation using anti-LRP-1 (clone 8G1 or EPR3724), anti- $\beta 1$-integrin (P4G11) antibodies, or nonspecific IgGs. For immunoprecipitation of biotinylated proteins, a concentration of $10 \mathrm{mM}$ D-biotin in PBS was first used for competitive elution of biotinylated proteins from avidin-agarose beads. Immunoprecipitation was performed by incubating samples with protein G-Sepharose beads (GE Healthcare) for $4 \mathrm{~h}$ at $4^{\circ} \mathrm{C}$ on an orbital agitator. Samples were washed three times in lysis buffer containing no Triton X-100. At last, bead-bound protein complexes were solubilized under non-reducing conditions and then analyzed by immunoblotting as described above.

\section{Endocytosis and recycling assays}

Biotin-based endocytosis assays were adapted from a validated biochemical method [37] and carried out as previously described [28]. FTC-133 cells were allowed to grow in 10\% FBS-containing medium in 10 $\mathrm{cm}$ dishes until they reached $80 \%$ confluency. Cells were then transferred on ice and then washed once with icecold PBS. Cell surface proteins were labeled using PBS containing $0.5 \mathrm{mg} . \mathrm{mL}^{-1}$ EZ-link cleavable sulfo-NHSSS-biotin (Thermofisher) for $30 \mathrm{~min}$ at $4^{\circ} \mathrm{C}$. Unbound biotin was removed with cold PBS before addition of prewarmed 10\% FBS-containing medium. Biotin-labeled surface proteins were allowed to internalize for $10 \mathrm{~min}$ at $37^{\circ} \mathrm{C}$, and then cells were quickly placed back on ice with cold PBS. After internalization, remaining biotin at the cell surface was removed by washing twice with $50 \mathrm{mM}$ glutathione (Sigma-Aldrich) in an appropriate buffer (10 mM EDTA, $75 \mathrm{mM} \mathrm{NaCl}, 75 \mathrm{mM} \mathrm{NaOH}$, pH 8.0 ) for $15 \mathrm{~min}$ at $4{ }^{\circ} \mathrm{C}$. To determine the total amount of surface biotinylation, one dish was kept on ice after biotin labeling and preserved from glutathione treatment. Cells were washed with ice-cold PBS and then lysed by scraping as described above. $350 \mu \mathrm{g}$ of biotinylated proteins were immunoprecipitated from the supernatant by adding $40 \mu \mathrm{L}$ of protein G-sepharose beads (GE Healthcare). Internalized integrins were detected by immunoblotting using anti- $\beta 1$-integrin antibody (M-106).

\section{Microscopy}

Following plating on gelatin-coated Lab-Tek I chambers, cells were maintained in phenol red-deprived DMEM-F12 (supplemented with low serum growth supplement and 10\% FBS) for epifluorescence video microscopy experiments. For bright field video microscopy, cells were observed over a 30 min period using a Zeiss Axiovert 200M equipped with a Coolsnap camera (Roper Scientific, Trenton, NJ, USA). Cells were maintained at $37^{\circ} \mathrm{C}$ in $5 \% \mathrm{CO}_{2}$ atmosphere using a temperature- controlled chamber (PECON, Erbach, Germany). Data were acquired using MetaMorph software (Roper Scientific). Timespan between image capture was $4 \mathrm{~s}$. Confocal microscopy images of fixed cells were collected with a Zeiss (Oberkochen, Germany) LSM710 Meta confocal microscope using either a $\times 63$ Plan Apochromat objective (oil immersion, $1.40 \mathrm{NA}$, DIC) at a $132 \mathrm{~nm}$. pixel $^{-1}$ resolution, leading to a slight $X Y$ oversampling. Optical slices were spaced by $1 \mu \mathrm{m}$ so as to limit $Z$ oversampling. Fluorescence filters were chosen and tested for each combination of plasmid construction and fluorescent dye so as to abolish spectral overlap. Zen software program was used to acquire images.

\section{Image processing}

Isosurface representations were realized using the AMIRA software program (v6.2; Visage Imaging, Berlin, Germany) as previously detailed in [28]. Acquired confocal stacks for vesicle (endosome/ lysosome) labeling were analyzed with a custom made Matlab script in order to determine the number of integrin-containing vesicles and to estimate the corresponding integrin amount from pixel intensity. Briefly, the script integrates data from a pair of stacks (vesicle labeling and integrin labeling). Images were first thresholded and then the fluorescence channels that correspond to vesicle immunostaining (i.e. Rab5a from endosome or LAMP-1 for lysosome) were analyzed to determine the pixels that are in close contact to each other (26-connected neighborhood) and therefore define the volume of each vesicle considered separately. Any vesicles $<7$ voxels were considered as artefact and removed from data analysis accordingly. The contour of remaining vesicles was then smoothed and compared to the channels corresponding to integrin labeling. The enabled, number/volume/shape of each vesicle to be measured, as well as the amount of labeled integrins contained within these vesicles. The script was automated in order to analyze wide collections of stacks therefore increasing the number of measurements. For video microscopy experiments, $\beta 1$-integrin DsRed $_{2}$ (DSR- $\beta 1-I T G)$ cluster trajectories were manually determined using the Point Picker ImageJ plugin.

\section{Data analysis}

All results presented raised from at least three independent experiments. Two sample bilateral $t$-test and ANOVA were used to compare assays (Prism software; GraphPad).

\section{Abbreviations}

ADAMTS, a disintegrin and metalloproteinase with thrombospondin motifs; DSR- $\beta 1$-ITG, DsRed ${ }_{2}$-tagged $\beta 1$ - 
integrin; ECM, extracellular matrix; ERK, extracellular signal-regulated kinases; FAK, focal adhesion kinase; FBS, fetal bovine serum; JNK, c-jun N-terminal kinase; LAMP-1, lysosomal-associated membrane protein-1; LRP-1, low-density lipoprotein receptor-relapted protein-1; MMP, matrix metalloproteinase; PAI-1, plasminogen activator inhibitor; RAP, receptor-associated protein; RFP, red fluorescent protein; SNX17, sorting nexin-17; uPA, urokinase plaminogen activator; uPAR, urokinase plaminogen activator receptor.

\section{Author contributions}

Stéphane Dedieu designed research. Louis Theret, Benoit Langlois, Sébastien Almagro and Cathy Hachet performed the research. MArion David, Michel Khrestchatisky contributed new reagents or analytic tool. Louis Theret, Jérôme Devy, Sébastien Almagro and Stéphane Dedieu analyzed data. Louis Theret, Albin Jeanne, Hervé Emonard and Stéphane Dedieu wrote papers.

\section{ACKNOWLEDGMENTS}

We acknowledge the expert technical support of C. Terryn (Cellular and Tissular Imaging Platform, Reims, France) for video microscopy and confocal microscopy experiments. We are grateful to Dr. D.K. Strickland (Department of Surgery, University of Maryland School of Medicine, Baltimore, MD, USA) for kindly providing us with the R2629 blocking antibody. The authors acknowledge N. J. Ward for editorial assistance.

\section{CONFLICTS OF INTEREST}

The authors declare no conflicts of interest.

\section{FUNDING}

This work was supported by grants from Ligue National Contre Le Cancer (CCIR-Grand Est), Centre National de la Recherche Scientifique (CNRS) and Université de Reims Champagne-Ardenne. L.T. and A.J. were supported by fellowships from the Ministère de l'Enseignement Supérieur et de la Recherche (20132016 and 2010-2013, respectively) and were recipients of mobility grants from the French Society for Extracellular Matrix Biology (SFBMEc) and French Society for Biochemistry and Molecular Biology (SFBBM).

\section{REFERENCES}

1. Beisiegel U, Weber W, Ihrke G, Herz J, Stanley KK. The LDL-receptor-related protein, LRP, is an apolipoprotein E-binding protein. Nature. 1989; 341: 162-4. https://doi. org/10.1038/341162a0.
2. Lillis AP, Muratoglu SC, Au DT, Migliorini M, Lee MJ, Fried SK, Mikhailenko I, Strickland DK. LDL receptorrelated protein-1 (LRP1) regulates cholesterol accumulation in macrophages. PLoS One. 2015; 10: e0128903. https:// doi.org/10.1371/journal.pone.0128903.

3. Strickland DK, Au DT, Cunfer P, Muratoglu SC. Lowdensity lipoprotein receptor-related protein-1: role in the regulation of vascular integrity. Arterioscler Thromb Vasc Biol. 2014; 34: 487-98. https://doi.org/10.1161/ ATVBAHA.113.301924.

4. Yepes M, Sandkvist M, Moore EG, Bugge TH, Strickland DK, Lawrence DA. Tissue-type plasminogen activator induces opening of the blood-brain barrier via the LDL receptor-related protein. J Clin Invest. 2003; 112: 1533-40. https://doi.org/10.1172/JCI19212.

5. Ramanathan A, Nelson AR, Sagare AP, Zlokovic BV. Impaired vascular-mediated clearance of brain amyloid beta in Alzheimer's disease: the role, regulation and restoration of LRP1. Front Aging Neurosci. 2015; 7: 136. https://doi. org/10.3389/fnagi.2015.00136.

6. Van Gool B, Dedieu S, Emonard H, Roebroek AJ. The matricellular receptor LRP1 forms an interface for signaling and endocytosis in modulation of the extracellular tumor environment. Front Pharmacol. 2015; 6: 271. https://doi. org/10.3389/fphar.2015.00271.

7. Li Y, Marzolo MP, van Kerkhof P, Strous GJ, Bu G. The YXXL motif, but not the two NPXY motifs, serves as the dominant endocytosis signal for low density lipoprotein receptor-related protein. J Biol Chem. 2000; 275: 1718794. https://doi.org/10.1074/jbc.M000490200.

8. Etique N, Verzeaux L, Dedieu S, Emonard H. LRP-1: a checkpoint for the extracellular matrix proteolysis. Biomed Res Int. 2013; 2013: 152163. https://doi. org/10.1155/2013/152163.

9. Emonard H, Bellon G, de Diesbach P, Mettlen M, Hornebeck W, Courtoy PJ. Regulation of matrix metalloproteinase (MMP) activity by the low-density lipoprotein receptor-related protein (LRP). A new function for an "old friend." Biochimie. 2005; 87: 369-76. https:// doi.org/10.1016/j.biochi.2004.11.013.

10. Czekay RP, Kuemmel TA, Orlando RA, Farquhar MG. Direct binding of occupied urokinase receptor (UPAR) to LDL receptor-related protein is required for endocytosis of UPAR and regulation of cell surface urokinase activity. Mol Biol Cell. 2001; 12: 1467-79. https://doi.org/10.1091/ mbc.12.5.1467.

11. Yang Z, Strickland DK, Bornstein P. Extracellular matrix metalloproteinase 2 levels are regulated by the low density lipoprotein-related scavenger receptor and thrombospondin 2. J Biol Chem. 2001; 276: 8403-8. https://doi.org/10.1074/ jbc.M008925200.

12. Hahn-Dantona E, Ruiz JF, Bornstein P, Strickland DK. The low density lipoprotein receptor-related protein modulates levels of matrix metalloproteinase 9 (MMP-9) by mediating 
its cellular catabolism. J Biol Chem. 2001; 276: 15498-503. https://doi.org/10.1074/jbc.M100121200.

13. Barmina OY, Walling HW, Fiacco GJ, Freije JM, LópezOtín C, Jeffrey JJ, Partridge NC. Collagenase-3 binds to a specific receptor and requires the low density lipoprotein receptor-related protein for internalization. J Biol Chem. 1999; 274: 30087-93.

14. Yamamoto K, Owen K, Parker AE, Scilabra SD, Dudhia J, Strickland DK, Troeberg L, Nagase H. Low density lipoprotein receptor-related protein 1 (LRP1)-mediated endocytic clearance of a disintegrin and metalloproteinase with thrombospondin motifs-4 (ADAMTS-4): functional differences of non-catalytic domains of ADAMTS-4 and ADAMTS-5 in LRP1 binding. J Biol Chem. 2014; 289: 6462-74. https://doi.org/10.1074/jbc.M113.545376.

15. Yamamoto K, Troeberg L, Scilabra SD, Pelosi M, Murphy CL, Strickland DK, Nagase H. LRP-1-mediated endocytosis regulates extracellular activity of ADAMTS-5 in articular cartilage. FASEB J. 2013; 27: 511-21. https://doi. org/10.1096/fj.12-216671.

16. Derocq D, Prébois C, Beaujouin M, Laurent-Matha V, Pattingre S, Smith GK, Liaudet-Coopman E. Cathepsin D is partly endocytosed by the LRP1 receptor and inhibits LRP1-regulated intramembrane proteolysis. Oncogene. 2012; 31: 3202-12. https://doi.org/10.1038/onc.2011.501.

17. Huang XY, Shi GM, Devbhandari RP, Ke AW, Wang Y, Wang XY, Wang Z, Shi YH, Xiao YS, Ding ZB, Dai Z, $\mathrm{Xu}$ Y, Jia WP, et al. Low level of low-density lipoprotein receptor-related protein 1 predicts an unfavorable prognosis of hepatocellular carcinoma after curative resection. PLoS One. 2012; 7: e32775. https://doi.org/10.1371/journal. pone. 0032775 .

18. de Vries TJ, Verheijen JH, de Bart AC, Weidle UH, Ruiter DJ, van Muijen GN. Decreased expression of both the low-density lipoprotein receptor-related protein/alpha(2)macroglobulin receptor and its receptor-associated protein in late stages of cutaneous melanocytic tumor progression. Cancer Res. 1996; 56: 1432-9.

19. Gilardoni MB, Ceschin DG, Sahores MM, Oviedo M, Gehrau RC, Chiabrando GA. Decreased expression of the low-density lipoprotein receptor-related protein-1 (LRP-1) in rats with prostate cancer. J Histochem Cytochem. 2003; 51: $1575-80$.

20. Dedieu S, Langlois B, Devy J, Sid B, Henriet P, Sartelet H, Bellon G, Emonard H, Martiny L. LRP-1 silencing prevents malignant cell invasion despite increased pericellular proteolytic activities. Mol Cell Biol. 2008; 28: 2980-95. https://doi.org/10.1128/MCB.02238-07.

21. Langlois B, Perrot G, Schneider C, Henriet P, Emonard H, Martiny L, Dedieu S. LRP-1 promotes cancer cell invasion by supporting ERK and inhibiting JNK signaling pathways. PLoS One. 2010; 5: e11584. https://doi.org/10.1371/journal. pone. 0011584 .

22. Chazaud B, Ricoux R, Christov C, Plonquet A, Gherardi RK, Barlovatz-Meimon G. Promigratory effect of plasminogen activator inhibitor-1 on invasive breast cancer cell populations. Am J Pathol. 2002; 160: 237-46. https:// doi.org/10.1016/S0002-9440(10)64367-2.

23. Montel V, Gaultier A, Lester RD, Campana WM, Gonias SL. The low-density lipoprotein receptor-related protein regulates cancer cell survival and metastasis development. Cancer Res. 2007; 67: 9817-24. https://doi. org/10.1158/0008-5472.CAN-07-0683.

24. Fayard B, Bianchi F, Dey J, Moreno E, Djaffer S, Hynes NE, Monard D. The serine protease inhibitor protease nexin-1 controls mammary cancer metastasis through LRP1-mediated MMP-9 expression. Cancer Res. 2009; 69: 5690-8. https://doi.org/10.1158/0008-5472.CAN-08-4573.

25. Hollenbach E, Ackermann S, Hyman BT, Rebeck GW. Confirmation of an association between a polymorphism in exon 3 of the low-density lipoprotein receptor-related protein gene and Alzheimer's disease. Neurology. 1998; 50: $1905-7$.

26. Benes P, Jurajda M, Zaloudík J, Izakovicová-Hollá L, Vácha J. C766T low-density lipoprotein receptor-related protein 1 (LRP1) gene polymorphism and susceptibility to breast cancer. Breast Cancer Res. 2003; 5: R77-81. https:// doi.org/10.1186/bcr591.

27. Martinez-Ledesma E, Verhaak RG, Treviño V. Identification of a multi-cancer gene expression biomarker for cancer clinical outcomes using a network-based algorithm. Sci Rep. 2015; 5: 11966. https://doi.org/10.1038/srep11966.

28. Perrot G, Langlois B, Devy J, Jeanne A, Verzeaux L, Almagro S, Sartelet H, Hachet C, Schneider C, Sick E, David M, Khrestchatisky M, Emonard H, et al. LRP-1-CD44, a new cell surface complex regulating tumor cell adhesion. Mol Cell Biol. 2012; 32: 3293-307. https://doi. org/10.1128/MCB.00228-12.

29. Orr AW, Pedraza CE, Pallero MA, Elzie CA, Goicoechea S, Strickland DK, Murphy-Ullrich JE. Low density lipoprotein receptor-related protein is a calreticulin coreceptor that signals focal adhesion disassembly. J Cell Biol. 2003; 161: 1179-89. https://doi.org/10.1083/jcb.200302069.

30. Dedieu S, Langlois B. LRP-1: a new modulator of cytoskeleton dynamics and adhesive complex turnover in cancer cells. Cell Adh Migr. 2008; 2: 77-80.

31. Desgrosellier JS, Cheresh DA. Integrins in cancer: biological implications and therapeutic opportunities. Nat Rev Cancer. 2010; 10: 9-22. https://doi.org/10.1038/ nrc2748.

32. Huttenlocher A, Horwitz AR. Integrins in cell migration. Cold Spring Harb Perspect Biol. 2011; 3: a005074. https:// doi.org/10.1101/cshperspect.a005074.

33. Appert-Collin A, Bennasroune A, Jeannesson P, Terryn C, Fuhrmann G, Morjani H, Dedieu S. Role of LRP-1 in cancer cell migration in 3-dimensional collagen matrix. Cell Adh Migr. 2017; 11: 316-26. https://doi.org/10.1080/19336 918.2016.1215788. 
34. Le Cigne A, Chièze L, Beaussart A, El-Kirat-Chatel S, Dufrêne YF, Dedieu S, Schneider C, Martiny L, Devy J, Molinari M. Analysis of the effect of LRP-1 silencing on the invasive potential of cancer cells by nanomechanical probing and adhesion force measurements using atomic force microscopy. Nanoscale. 2016; 8: 7144-54. https://doi. org/10.1039/c5nr08649c.

35. Spijkers PP, da Costa Martins P, Westein E, Gahmberg CG, Zwaginga JJ, Lenting PJ. LDL-receptor-related protein regulates beta2-integrin-mediated leukocyte adhesion. Blood. 2005; 105: 170-7. https://doi.org/10.1182/ blood-2004-02-0498.

36. Arjonen A, Alanko J, Veltel S, Ivaska J. Distinct recycling of active and inactive $\beta 1$ integrins. Traffic. 2012; 13: 610 25. https://doi.org/10.1111/j.1600-0854.2012.01327.x.

37. Wu L, Gonias SL. The low-density lipoprotein receptorrelated protein-1 associates transiently with lipid rafts. J Cell Biochem. 2005; 96: 1021-33. https://doi.org/10.1002/ jcb.20596.

38. Mikhailenko I, Battey FD, Migliorini M, Ruiz JF, Argraves K, Moayeri M, Strickland DK. Recognition of alpha 2-macroglobulin by the low density lipoprotein receptorrelated protein requires the cooperation of two ligand binding cluster regions. J Biol Chem. 2001; 276: 39484-91. https://doi.org/10.1074/jbc.M104382200.

39. Thevenard J, Verzeaux L, Devy J, Etique N, Jeanne A, Schneider C, Hachet C, Ferracci G, David M, Martiny L, Charpentier E, Khrestchatisky M, Rivera S, et al. Low-density lipoprotein receptor-related protein-1 mediates endocytic clearance of tissue inhibitor of metalloproteinases- 1 and promotes its cytokine-like activities. PLoS One. 2014; 9: e103839. https://doi. org/10.1371/journal.pone.0103839.

40. Dozynkiewicz MA, Jamieson NB, Macpherson I, Grindlay J, van den Berghe PV, von Thun A, Morton JP, Gourley C, Timpson P, Nixon C, McKay CJ, Carter R, Strachan D, et al. Rab25 and CLIC3 collaborate to promote integrin recycling from late endosomes/lysosomes and drive cancer progression. Dev Cell. 2012; 22: 131-45. https://doi. org/10.1016/j.devcel.2011.11.008.

41. Song H, Li Y, Lee J, Schwartz AL, Bu G. Low-density lipoprotein receptor-related protein 1 promotes cancer cell migration and invasion by inducing the expression of matrix metalloproteinases 2 and 9. Cancer Res. 2009; 69: 879-86. https://doi.org/10.1158/0008-5472. CAN-08-3379.

42. Lo SH. Focal adhesions: what's new inside. Dev Biol. 2006; 294: 280-91. https://doi.org/10.1016/j. ydbio.2006.03.029.

43. Brakebusch C, Fässler R. $\beta 1$ integrin function in vivo: adhesion, migration and more. Cancer Metastasis Rev. 2005; 24: 403-11. https://doi.org/10.1007/s10555-005-5132-5.

44. Cao C, Lawrence DA, Li Y, Von Arnim CA, Herz J, Su EJ, Makarova A, Hyman BT, Strickland DK, Zhang L. Endocytic receptor LRP together with tPA and PAI-1 coordinates Mac-1-dependent macrophage migration. EMBO J. 2006; 25: 1860-70. https://doi.org/10.1038/ sj.emboj.7601082.

45. Ranganathan S, Cao C, Catania J, Migliorini M, Zhang L, Strickland DK. Molecular basis for the interaction of low density lipoprotein receptor-related protein 1 (LRP1) with integrin alphaMbeta2: identification of binding sites within alphaMbeta2 for LRP1. J Biol Chem. 2011; 286: 30535-41. https://doi.org/10.1074/jbc.M111.265413.

46. Rabiej VK, Pflanzner T, Wagner T, Goetze K, Storck SE, Eble JA, Weggen S, Mueller-Klieser W, Pietrzik CU. Low density lipoprotein receptor-related protein 1 mediated endocytosis of $\beta 1$-integrin influences cell adhesion and cell migration. Exp Cell Res. 2016; 340: 102-15. https:/doi. org/10.1016/j.yexcr.2015.11.020.

47. Alanko J, Mai A, Jacquemet G, Schauer K, Kaukonen R, Saari M, Goud B, Ivaska J. Integrin endosomal signalling suppresses anoikis. Nat Cell Biol. 2015; 17: 1412-21. https://doi.org/10.1038/ncb3250.

48. Böttcher RT, Stremmel C, Meves A, Meyer H, Widmaier M, Tseng HY, Fässler R. Sorting nexin 17 prevents lysosomal degradation of $\beta 1$ integrins by binding to the $\beta 1$-integrin tail. Nat Cell Biol. 2012; 14: 584-92. https:// doi.org/10.1038/ncb2501.

49. Steinberg F, Heesom KJ, Bass MD, Cullen PJ. SNX17 protects integrins from degradation by sorting between lysosomal and recycling pathways. J Cell Biol. 2012; 197 : 219-30. https://doi.org/10.1083/jcb.201111121.

50. Farfán P, Lee J, Larios J, Sotelo P, Bu G, Marzolo MP. A sorting nexin 17-binding domain within the LRP1 cytoplasmic tail mediates receptor recycling through the basolateral sorting endosome. Traffic. 2013; 14: 823-38. https://doi.org/10.1111/tra.12076.

51. van Kerkhof P, Lee J, McCormick L, Tetrault E, Lu W, Schoenfish M, Oorschot V, Strous GJ, Klumperman J, $\mathrm{Bu}$ G. Sorting nexin 17 facilitates LRP recycling in the early endosome. EMBO J. 2005; 24: 2851-61. https://doi. org/10.1038/sj.emboj.7600756.

52. Lahlou H, Muller WJ. $\beta 1$-integrins signaling and mammary tumor progression in transgenic mouse models: implications for human breast cancer. Breast Cancer Res. 2011; 13: 229. https://doi.org/10.1186/bcr2905.

53. Sottnik JL, Daignault-Newton S, Zhang X, Morrissey C, Hussain MH, Keller ET, Hall CL. Integrin alpha2beta 1 $(\alpha 2 \beta 1)$ promotes prostate cancer skeletal metastasis. Clin Exp Metastasis. 2013; 30: 569-78. https://doi.org/10.1007/ s10585-012-9561-6.

54. Mitchell K, Svenson KB, Longmate WM, Gkirtzimanaki K, Sadej R, Wang X, Zhao J, Eliopoulos AG, Berditchevski F, Dipersio CM. Suppression of integrin alpha3betal in breast cancer cells reduces cyclooxygenase- 2 gene expression and inhibits tumorigenesis, invasion, and cross-talk to endothelial cells. Cancer Res. 2010; 70: 6359-67. https:// doi.org/10.1158/0008-5472.CAN-09-4283. 
55. Adachi M, Taki T, Higashiyama M, Kohno N, Inufusa H, Miyake M. Significance of integrin alpha5 gene expression as a prognostic factor in node-negative non-small cell lung cancer. Clin Cancer Res. 2000; 6: 96-101.

56. Cosset EC, Godet J, Entz-Werlé N, Guérin E, Guenot D, Froelich S, Bonnet D, Pinel S, Plenat F, Chastagner P, Dontenwill M, Martin S. Involvement of the TGF $\beta$ pathway in the regulation of $\alpha 5 \beta 1$ integrins by caveolin-1 in human glioblastoma. Int J Cancer. 2012; 131: 601-11. https://doi. org/10.1002/ijc.26415.

57. Katoh D, Nagaharu K, Shimojo N, Hanamura N, Yamashita M, Kozuka Y, Imanaka-Yoshida K, Yoshida T. Binding of $\alpha v \beta 1$ and $\alpha v \beta 6$ integrins to tenascin- $C$ induces epithelialmesenchymal transition-like change of breast cancer cells. Oncogenesis. 2013; 2: e65. https://doi.org/10.1038/ oncsis.2013.27.

58. Skalski M, Coppolino MG. SNARE-mediated trafficking of $\alpha 5 \beta 1$ integrin is required for spreading in $\mathrm{CHO}$ cells. Biochem Biophys Res Commun. 2005; 335: 1199-210. https://doi.org/10.1016/j.bbrc.2005.07.195.

59. Sid B, Dedieu S, Delorme N, Sartelet H, Rath GM, Bellon G, Martiny L. Human thyroid carcinoma cell invasion is controlled by the low density lipoprotein receptor-related protein-mediated clearance of urokinase plasminogen activator. Int J Biochem Cell Biol. 2006; 38: 1729-40. https://doi.org/10.1016/j.biocel.2006.04.005.

60. Salicioni AM, Gaultier A, Brownlee C, Cheezum MK, Gonias SL. Low density lipoprotein receptor-related protein-1 promotes beta1 integrin maturation and transport to the cell surface. J Biol Chem. 2004; 279: 10005-12. https://doi.org/10.1074/jbc.M306625200.

61. Eke I, Deuse Y, Hehlgans S, Gurtner K, Krause M, Baumann M, Shevchenko A, Sandfort V, Cordes N. $\beta_{1}$ Integrin/FAK/ cortactin signaling is essential for human head and neck cancer resistance to radiotherapy. J Clin Invest. 2012; 122: 1529-40. https://doi.org/10.1172/JCI61350.
62. Huang C, Park CC, Hilsenbeck SG, Ward R, Rimawi MF, Wang YC, Shou J, Bissell MJ, Osborne CK, Schiff R. $\beta 1$ integrin mediates an alternative survival pathway in breast cancer cells resistant to lapatinib. Breast Cancer Res. 2011; 13: R84. https://doi.org/10.1186/bcr2936.

63. Kanda R, Kawahara A, Watari K, Murakami Y, Sonoda K, Maeda M, Fujita H, Kage M, Uramoto H, Costa C, Kuwano M, Ono M. Erlotinib resistance in lung cancer cells mediated by integrin $\beta 1 / \mathrm{Src} /$ Akt-driven bypass signaling. Cancer Res. 2013; 73: 6243-53. https://doi. org/10.1158/0008-5472.CAN-12-4502.

64. Naci D, El Azreq MA, Chetoui N, Lauden L, Sigaux F, Charron D, Al-Daccak R, Aoudjit F. $\alpha 2 \beta 1$ integrin promotes chemoresistance against doxorubicin in cancer cells through extracellular signal-regulated kinase (ERK). J Biol Chem. 2012; 287: 17065-76. https://doi.org/10.1074/ jbc.M112.349365.

65. Janouskova H, Maglott A, Leger DY, Bossert C, Noulet F, Guerin E, Guenot D, Pinel S, Chastagner P, Plenat F, EntzWerle N, Lehmann-Che J, Godet J, et al. Integrin $\alpha 5 \beta 1$ plays a critical role in resistance to temozolomide by interfering with the p53 pathway in high-grade glioma. Cancer Res. 2012; 72: 3463-70. https://doi.org/10.1158/0008-5472. CAN-11-4199.

66. Wang T, Srivastava S, Hartman M, Buhari SA, Chan CW, Iau P, Khin LW, Wong A, Tan SH, Goh BC, Lee SC. High expression of intratumoral stromal proteins is associated with chemotherapy resistance in breast cancer. Oncotarget. 2016; 7: 55155-68. https://doi.org/10.18632/ oncotarget. 10894.

67. Campbell RE, Tour O, Palmer AE, Steinbach PA, Baird GS, Zacharias DA, Tsien RY. A monomeric red fluorescent protein. Proc Natl Acad Sci U S A. 2002; 99: 7877-82. https://doi.org/10.1073/pnas.082243699. 